\title{
Persistent organic pollutants and obesity: are they potential mechanisms for breast cancer promotion?
}

\author{
Denise K Reaves, Erika Ginsburg', John J Bang ${ }^{2}$ and Jodie M Fleming \\ Department of Biology, North Carolina Central University, MTSC Room 2247, 1801 Fayetteville Street, Durham, \\ North Carolina 27707, USA \\ ${ }^{1}$ National Cancer Institute, National Institutes of Health, Center for Cancer Training, Bethesda, Maryland 20892, USA \\ ${ }^{2}$ Department of Biology, North Carolina Central University, Durham, North Carolina 27707, USA
}

\author{
Correspondence \\ should be addressed \\ to $J$ M Fleming \\ Email \\ Jodie.fleming@nccu.edu
}

\begin{abstract}
Dietary ingestion of persistent organic pollutants (POPs) is correlated with the development of obesity. Obesity alters metabolism, induces an inflammatory tissue microenvironment, and is also linked to diabetes and breast cancer risk/promotion of the disease. However, no direct evidence exists with regard to the correlation among all three of these factors (POPs, obesity, and breast cancer). Herein, we present results from current correlative studies indicating a causal link between POP exposure through diet and their bioaccumulation in adipose tissue that promotes the development of obesity and ultimately influences breast cancer development and/or progression. Furthermore, as endocrine disruptors, POPs could interfere with hormonally responsive tissue functions causing dysregulation of hormone signaling and cell function. This review highlights the critical need for advanced in vitro and in vivo model systems to elucidate the complex relationship among obesity, POPs, and breast cancer, and, more importantly, to delineate their multifaceted molecular, cellular, and biochemical mechanisms. Comprehensive in vitro and in vivo studies directly testing the observed correlations as well as detailing their molecular mechanisms are vital to cancer research and, ultimately, public health.
\end{abstract}

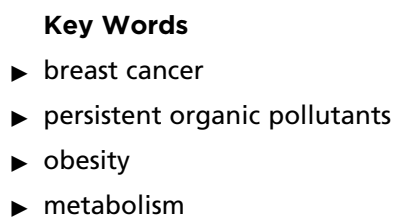

\section{Introduction}

Persistent organic pollutants (POPs), a group of chemicals such as organochlorine pesticides (OCPs) and polychlorinated biphenyls (PCBs), are ubiquitous pollutants found globally. These chemicals have common properties of persistence including lipophilicity, toxicity, and bioaccumulation (Woodwell 1967, Lee et al. 2010). Owing to their highly lipophilic properties, POPs (organohydrocarbons with chlorine, fluoride, and bromine groups) are most notably resistant to degradation in both humans and the environment, thus proving to be a bigger threat to global health (Yu et al. 2011). With their half-lives varying from months to decades due to their high lipid solubility that allows them to resist biological, photolytic, and chemical degradation, POPs are also semi-volatile allowing them to evaporate into the atmosphere and be deposited back to the earth in precipitates (Thundiyil et al. 2007). The Stockholm Convention on POPs was adopted on May 22nd, 2001, and entered into force on May 17th, 2004 with the goal of managing, cleaning, and eliminating the production of POPs in the environment. In the USA, production and

Published by Bioscientifica Ltd 
distribution of many POPs have been banned under the Safe Chemicals Act of 2011. However, according to the Environmental Protection Agency and other regulatory sources, chronic POP exposure continues due to contamination of the food chain, in both artificial and natural environments, and their continued use in under-developed countries with little to no regulation (Ritter et al. 2002, Weber et al. 2008, Noyes et al. 2009, Lee et al. 2010, La Merrill et al. 2013, Ljunggren et al. 2014). Accumulation of POPs in adipose tissues has been proposed to be the probable stimulus for their pathological manifestations. While nonlipophilic POPs are not the focus of this review, it is important to note that compounds such as perfluorooctane sulfonate (PFOS) and perfluorooctanoic acid, commonly used in industry as flame retardants and fabric protectors, do not accumulate in fatty tissue but bioaccumulate due to their extremely stable carbon-fluorine bonds. These POPs have been shown to bind to proteins, ultimately interfering with their function (Jones et al. 2003, DeWitt et al. 2012, Domingo 2012, Corsini et al. 2014). Exposure to any type of POPs has the potential for long-term disruption of metabolic, immune, and endocrine system functions. Consequently, POPs are increasingly becoming the subject of research and public health attention due to their strong link to type 2 diabetes, metabolic syndrome, and cancer, each of which is intimately linked to obesity (Lee et al. 2010, Prieto-Hontoria et al. 2011, Park et al. 2014a). Human exposure to POPs occurs through consumption of seafood and livestock and, because POPs are water-insoluble and not easily metabolized, they accumulate in adipose tissue (Woodwell 1967, Lee et al. 2010).

As endocrine disruptors, POPs interfere with hormonally responsive tissue functions via dysregulation of hormone signaling and cell function (Solomon \& Schettler 2000, Pombo \& Castro-Feijoo 2005, Lara et al. 2012, Meeker 2012, Rylander et al. 2014). Specific to this review, dysregulation of estrogen, progesterone, and prolactin, important breast development hormones, can cause a multitude of growth dysfunctions including fibrocystic breast disease and/or breast cancer (Vonderhaar 1988, Hovey et al. 2002). Breast development is unique compared with other major organs as the majority of development occurs after birth. Rudimentary epithelial and stromal growth is isometric until the onset of puberty, whereupon allometric growth of the epithelial ducts and supportive stromal tissues occurs (Hassiotou \& Geddes 2013). Postpuberty, breast tissue continues to proliferate and regress in response to hormonal stimuli during each menstruation cycle. Depending on the woman's life choices, subsequent key developmental stages may include pregnancy-, lactation-, and postlactation-associated remodeling. Ultimately, every woman experiences postmenopausal involution, initiated via declining ovarian function and subsequent decreased circulating estrogen and progesterone levels. Atrophy and regression of glandular epithelium with a concurrent increase in adipose tissue and a reduced elasticity of the supporting connective tissue are observed (Hassiotou \& Geddes 2013). In summary, breast tissue is highly dynamic throughout a woman's life, and during any of these unique stages, a disruption in the delicate balance of growth factor and hormonal signaling between the stroma and epithelium has the potential to promote disease.

The global obesity epidemic compounds any predisposition to breast disease due to changes in hormone and growth factor signaling. Obesity and metabolic syndrome promotes an inflammatory microenvironment, thereby disrupting tissue homeostasis (Park et al. 2014a). An inflammatory microenvironment is known to promote aggressive breast cancer cell behaviors and affect tumor subtype, ultimately leading to poor prognosis and decreased survival (Sun et al. 2012, Ham \& Moon 2013, Nguyen et al. 2013, Casbas-Hernandez et al. 2014, Rose \& Vona-Davis 2014). Consumption and bioaccumulation of POPs in adipose tissue enhance the obesity-driven dysregulation of cell function, as accumulation of POPs has been proposed to promote obesity (Woodwell 1967, Lee et al. 2010). Thus, the potential exists for POPs and obesity-related factors to work together in a self-reinforcing mode to magnify the effects of endocrine disruption and altered cell signaling, thereby increasing the risk of developing breast cancer or of existing tumors progressing into more aggressive subtypes. Herein, we highlight the potential interaction among POP accumulation, development of obesity, and breast cancer.

\section{Adipose tissue and POP localization}

Each adipose tissue depot (serum, subcutaneous, visceral, and inter-muscular) has differing endocrine, metabolic, and cell signaling functions (Gilsanz et al. 2013, La Merrill et al. 2013, Bloor \& Symonds 2014, Rosenwald \& Wolfrum 2014). Women are unique in that they possess an additional, highly dynamic, and functional source of adipose cells in their breast tissue. Within each of these adipose depots resides a multitude of different cell subtypes. White adipocyte tissue (WAT), found mainly around the waist and thighs, has cells containing a single lipid droplet that function as energy stores that secrete various hormones with endocrine and immune functions.

Published by Bioscientifica Ltd. 
Residing in WAT are brown adipocytes derived from precursor cells differing from classical brown adipocytes that are closer to the white adipocyte cell lineage termed 'brite adipocytes'. These brite cells appear at anatomical sites corresponding to WAT after thermogenic stimuli (Giralt \& Villarroya 2013). Conversely, brown adipocyte tissue (BAT) is primarily involved in body temperature maintenance (non-shivering thermogenesis) and body adiposity. In adult humans, BAT is mainly found around the cervical-supraclavicular area, and has cells containing many small lipid droplets, a high number of mitochondria, higher oxygen consumption, high capillary perfusion, and sympathetic nervous system innervation (Seale \& Lazar 2009, Seale et al. 2009, Gilsanz et al. 2013, Bloor \& Symonds 2014, Rosenwald \& Wolfrum 2014). Lipid droplet proteins have been shown to regulate BAT metabolism in adult mice, while the role of human BAT metabolism, as well as their overall function, needs further analyses in order to fully appreciate their physiological roles (Seale \& Lazar 2009, Seale et al. 2009, Giralt \& Villarroya 2013). Notably, poor BAT activity in humans correlates with aging, BMI, and measures of metabolic disease, and the study of adipocyte transdifferentiation mechanisms may lead to therapeutic strategies against metabolic syndrome and cellular metabolic dysregulation observed in breast cancer (Seale \& Lazar 2009, Seale et al. 2009, Giralt \& Villarroya 2013, Giordano et al. 2014).

In women, a large source of WAT can be found in breast tissue. Adipose tissue comprises the majority of breast volume and is altered due to puberty, pregnancy, lactation, and menopause (Hassiotou \& Geddes 2013). During puberty, periductal connective tissue is generated in breast adipose tissue with thickening and elongation of the ductal system. In pregnancy and lactation, active glandular tissue doubles in relation to adipose tissue but reverts once lactation ceases. Starting at around the age of 40 , ductal and lobular breast tissues begin to atrophy with involution of glandular tissue that is replaced by fat and connective tissue. Both systemic and local growth factors direct this continual remodeling of the gland. Breast adipocyte secretion of adipokines, cytokines, and hormones such as estrogen has been linked to numerous biological processes including cell proliferation, communication, immune response, apoptosis, and cell metabolism (Park et al. 2014a). Estrogens also regulate adipose tissue deposition, adipogenesis, and adipocyte differentiation. Any dysregulation in the production or distribution of estrogens could lead to disease or breast cancer (Park et al. 2014b, Planey et al. 2014). Moreover, it has been shown that adipocytes can be manipulated by cancer cells to promote tumor invasion, characterized by adipocyte hypertrophy and the accumulation of neutrophils and macrophages in adipose tissue, creating an imbalance and poor prognosis for cancer patients (Prieto-Hontoria et al. 2011, Park et al. 2014a).

Adipose tissue contains high levels of aromatase, an enzyme that converts androgens to estrogen (Simpson 2003). In obesity, estrogen levels have been shown to be increased in postmenopausal women, but decreased in premenopausal women (De Pergola \& Silvestris 2013, Suba 2013). These obesity-driven changes in estrogen regulation have been suggested to play a role in the complex relationship to premenopausal and postmenopausal breast cancer, and the clinical behavior of the disease. Results from a meta-analysis of seven cohort studies were indicative of a direct link between obesity and an elevated risk of breast cancer in postmenopausal women, with the inverse being true in premenopausal women (van den Brandt et al. 2000). However, obesity is correlated with advanced disease at diagnosis and poor prognosis at any age (van den Brandt et al. 2000, Stephenson \& Rose 2003). Furthermore, excessive weight gain during pregnancy, fetal exposure to high-fat diet, high birth weight, and postnatal exposure to high-fat diets during lactation have each been shown to increase breast cancer susceptibility and development in adults in carcinogen-induced rat model studies (HilakiviClarke et al. 2004, 2005, De Assis \& Hilakivi-Clarke 2006, Hilakivi-Clarke \& de Assis 2006, de Oliveira Andrade et al. 2014). Collectively, these results indicate that in addition to increased risk of cancer later in life, childhood obesity and obesity-related intrauterine factors may ultimately increase breast cancer risk in women.

Results from a recent study focused on understanding the effects of POP exposure on adipose tissue indicated that exposure of human preadipocytes to PCB126 affected their ability to differentiate into mature adipocytes. PCB126 stimulated intrinsic changes in cell function by decreasing transcript levels of a key regulator of adipogenesis, PPAR $\gamma$ (Gadupudi et al. 2014). The ability of preadipocytes to mature is integral to development and homeostasis. POP exposure compromising the ability of preadipocytes to differentiate in children and adolescents has the potential to alter their ability to form normal adipose tissue, ultimately leading to dysfunction and disease. In adults, chronic POP exposure may alter their ability to replace mature adipocytes produced by cell death, again potentially leading to dysfunctional adipose tissue (Gadupudi et al. 2014).

Two well-studied sources of adipose tissue are visceral and subcutaneous tissues, each having unique physiological and clinical features. In a study investigating POP content of

Published by Bioscientifica Ltd 
these sources, Korean patients $(n=50)$ undergoing surgery for gallbladder or liver lesions had samples isolated and tested for a set of POP congeners (Kim et al. 2014). POP accumulation was correlated with both sources of adipose cells. However, researchers found five to ten times higher absolute concentration of PCB congeners in visceral adipose tissue (VAT) versus subcutaneous adipose tissue (SAT). A pattern also emerged in patients with diabetes, showing a set of OCPs and PCB congeners significantly correlated with VAT (Kim et al. 2014). The authors proposed that these correlations may be due to biological properties of the VAT adipocytes as these cells have enhanced sensitivity to lipolysis, are more metabolically active, and have increased insulin resistance compared with SAT. Given the emerging complex biological roles of adipose tissue, it is important to ascertain whether POPs are distributed equally throughout all adipose tissue sources in the body or are preferentially localized.

In a parallel study, Yu and colleagues analyzed ten PCB congeners and OCPs in serum levels of both lean and obese subjects. Serum samples, and visceral and subcutaneous adipose tissue biopsies were taken from subjects during laparotomy and evaluated. Overall, higher levels of OCPs were found in VAT while PCBs accumulated more readily in SAT (Yu et al. 2011). Variations were attributed to exposure level, BMI, and genetic differences between the subjects, highlighting the fact that POP-containing food sources vary between geographical regions, and within ethnicities. This study is very limited $(n=7)$ with only one woman included in this report, and despite sex-specific adipose tissue distribution, few studies have involved direct observation of sex differences with respect to POP accumulation. A recent, more comprehensive study evaluated the accumulation of 13 types of POPs and in VAT and SAT from Portuguese obese (>35 BMI) bariatric surgery patients $(n=189)$ of which 166 were females (Pestana et al. 2014). While sex and breast adipose tissue were also not specifically studied in this report, the data confirm those found in the studies by Kim et al. (2010) and Yu et al. (2011) Pestana and colleagues demonstrated that POPs were prevalent in this obese population (96.3\% detection in both tissues), and their abundance increased with age and duration of obesity. An increase in POP deposition in VAT, a positive correlation between POP levels and the presence of metabolic syndrome, and a relationship between higher POP levels and lower weight loss in older patients were observed (Pestana et al. 2014).

While none of these studies focussed on sex differences, women tend to have overall higher adipose tissue levels, with the majority localized to the hips and thighs
(Karastergiou et al. 2012) and a significant amount in breast tissue, while men tend to exhibit a preferential accumulation of abdominal adipose tissue. Limited information exists on breast adipose tissue and POP accumulation. Papers describing three methods have directly demonstrated POP accumulation in breast adipose tissue; however, no analysis of health or etiology of disease was performed. In the first report the use of chromatography-time-of-flight mass spectrometry (GC-TOF MS) for screening anthropogenic organic contaminants in 40 human breast adipose tissues was validated and it was demonstrated that both target and non-target approaches detected pollutants including $p, p^{\prime}$-dichloro-diphenyl-dichloroethylene ( $p, p^{\prime}$-DDE), hexachlorobenzene (HCB), and several PCBs, polyaromatic hydrocarbons (PAHs), 5-di-tert-butyl-4-hydroxy-toluene (BHT) and its metabolite 3,5-di-tert-butyl-4-hydroxybenzaldehyde (BHT-CHO), and dibenzylamine, $\mathrm{N}$-butyl benzenesulfonamide (N-BBSA) (Hernandez et al. 2009). In the second report by the same authors a multiresidue method for the quantification and confirmation of 30 organohalogenated compounds in human breast tissue samples was used (Medina et al. 2009). Finally, the presence of prevalent dioxins, furans, PCBs, OCPs, and brominated diphenyl ethers in both breast and abdominal adipose tissues of 21 women was reported. These results indicate that, with some notable exceptions, measurements in breast and abdominal adipose tissues were correlated and that concentrations of POPs in one tissue could be derived from measurements of the other tissue (Petreas et al. 2004). Again, no functional studies on the effects of these POPs on cell behavior were performed; however, these results highlight the accumulation of the potentially disruptive POPs in the breast microenvironment.

In support of lipid-specific accumulation, the levels of PCBs uptake were directly correlated with triglyceride levels in adipocyte cell lipid droplets (Bourez et al. 2012, 2013). Lipid droplets are organelles composed of a phospholipid monolayer and a lipid ester core that occupy a large portion of cell volume in many cells including those from mammals, plants, and microorganisms. Obesity, characterized by excessive adipocytes, is essentially a disease of lipid droplet excess (Walther \& Farese 2009). To identify rate of absorption and localization of PCBs into cells, Bourez and colleagues assayed the well-characterized 3T3-L1 murine cell model system for adipogenesis, as well as primary murine embryonic adipocytes by exposing them to a cocktail of PCB congeners. After 90 min of incubation, the majority of all congeners were recovered inside the differentiated adipocytes, and not the control pre-differentiated fibroblasts. After $24 \mathrm{~h}$, the intracellular

Published by Bioscientifica Ltd. 
PCB accumulation was almost exclusively recovered in the high-triglyceride-containing lipid droplet fraction of the adipocytes compared with the membrane fraction (Bourez et al. 2012), indicating that PCB accumulation in adipocytes is dependent on the triglyceride content of the adipose tissue, and highlighting the potential for a greater risk of accumulation of POPs in obese subjects. A limitation of this study is the use of murine cells and cell lines. It is not known whether human preadipocytes would have a similar cellular differentiation process in the presence of the PCB congeners, or whether human adipocytes would display similar uptake patterns of the congeners used in the study.

Complementing these studies, Gutleb et al. (2012) developed a method to visualize cellular localization and semi-quantitatively calculate concentrations of halogenated POPs via secondary ion mass spectrometry. Using a human adrenocortical carcinoma and a rat pituitary tumor cell line, bromine-containing POP tetrabromobisphenol A (TBBPA; a commonly used flame retardant) and the fluorine POP PFOS (a fabric protector) were localized to the lipid bilayer of cell membranes (Gutleb et al. 2012). Again, a limitation of this study is the lack of normal/nontransformed human cells and tissues to observe POP incorporation and localization. It is not known whether the effects of POP localization in tumor cells would be applicable to normal human epithelial cells, given the welldocumented altered cellular metabolism and membrane lipid content of cancer cells (Siddiqui et al. 2007, Baumann et al. 2013, Zaidi et al. 2013, Ibarguren et al. 2014). To date, no additional studies have investigated been performed to investigate such detailed molecular localization of POPs in human tissues and/or cell culture model systems.

This would be of particular interest in breast tissue, as the specific mechanisms of fatty acid uptake in breast epithelium during various human developmental stages (puberty, pregnancy, lactation, involution) have not been as well identified compared with those of rodents and livestock (Barber et al. 1997, McManaman 2014). Lipophilic POPs might be endocytosed by cells via LPL and CD36, two proposed mediators of breast lipid endocytosis (Kuemmerle et al. 2011, McManaman 2014). The significant increase in epithelial cell lipid uptake during lactation to produce milk proteins indicates a potential route of transmission of POPs from mother to the developing child.

In a developmental study on prenatal exposure to POPs, Valvi et al. (2014) collected information on pregnant women and their infants $(n=1285)$ in a population-based birth cohort study. POP concentrations (dichlorodiphenyltrichloroethane (DDT), DDE, HCB, $\beta$-hexachlorocyclohexane ( $\beta \mathrm{HCH})$, and the PCB congeners $28,52,101,118,138,153$, and 180) were measured in serum collected from pregnant women during the 7 th and 26th weeks of pregnancy (Valvi et al. 2014). The infant model included age, sex, gestational age, breast feeding duration, and several maternal characteristics. The researchers found that prenatal exposure to DDE and HCB was associated with rapid growth in the first 6 months and resulted in overweight infants at 14 months. This indicates a direct link between childhood obesity and prenatal exposure to POPs. Interestingly, prenatal growth was not influenced by PCB exposure (Valvi et al. 2014), suggesting different mechanisms for various POPs. Human exposure to POPs is unavoidable; however, to understand tissue-specific differences in metabolism of POPs as well as cell-type-specific reactions and localization, further studies are needed.

Studies investigating the mechanisms of cellular uptake and localization of POPs in breast cells (epithelium versus adipose) would further advance our understanding of breast and lactation physiology as well as cellular lipid metabolism. Moreover, detailing the alterations in the uptake and localization of POPs in cancer cells and their tumor microenvironment, compared with healthy breast epithelium and supportive stroma, may provide further insights into the transition of cellular lipid metabolism and dysregulation of cellular respiration during tumorigenesis.

\section{Obesity and POPs}

Adipose tissue is classified as a metabolically active endocrine organ and obesity-induced dysregulation stimulates an enhanced inflammatory tissue microenvironment, including altered secretion of chemokines/cytokines (monocyte chemotactic protein 1 , interleukin 6 , and tumor necrosis factor $\alpha$ ) and adipokines (haptogolin, PAI, leptin, resistan, visfatin, adiponectin, and VEGF) (Prieto-Hontoria et al. 2011, Myre \& Imbeault 2014). Obesity-stimulated production of these factors is directly correlated with conditions such as chronic inflammation, cardiovascular disease, atherosclerosis, cancer (including breast cancer), and lipotoxicity (Prieto-Hontoria et al. 2011). Moreover, emerging evidence indicates a strong relationship between POPs, obesity, and the development and/or progression of disease (Bourez et al. 2012, 2013, La Merrill et al. 2013, Taylor et al. 2013, Ljunggren et al. 2014, Magliano et al. 2014, Myre \& Imbeault 2014, PereiraFernandes et al. 2014). The 'obesogen hypothesis' postulates that chemical pollutants (obesogens) promote obesity by disrupting appetite controls and promoting adipocyte

Published by Bioscientifica Ltd. 
hypertrophy and hyperplasia, thereby causing weight gain (Baillie-Hamilton 2002, Grun \& Blumberg 2006, Decherf \& Demeneix 2011, Pereira-Fernandes et al. 2014). The links between dysregulated adipose tissue in lipid metabolism, cancer, cardiovascular disease, and diabetes have been extensively researched (Prieto-Hontoria et al. 2011, Matsuda \& Shimomura 2013, Schwab et al. 2014). The molecular mechanisms of POP signaling driving the development or progression of these diseases are yet to be fully understood.

Dirinck et al. (2011) assessed the association between serum POP levels and the prevalence of obesity in a crosssectional study of 98 obese and 47 lean adults. BMI, glucose tolerance, adipose storage deposits, and measurements of waist and hip circumference were recorded, and serum levels were analyzed for lipophilic PCB congeners $153,138,180$, and 170, and for the hydrophilic OCPs: $\mathrm{pp}$-DDE and $\mathrm{BHCH}$. These results indicated that as BMI increased the serum levels of highly lipophilic congeners decreased. The converse was true for the less lipophilic congeners (Dirinck et al. 2011). The authors suggested that the lipophilic POPs are preferably stored in adipose tissue and a higher percentage of body fat will lead to fast and efficient storage, with lower serum levels as a consequence. While not discussed herein, this inverse relationship has been observed by others (Wolff et al. 2005, Agudo et al. 2009). In the study by Dirinck and colleagues serum $\beta \mathrm{HCH}$ had a significant positive correlation with BMI in both sexes. In females, fat mass percentage and increased waist circumference had a significant negative correlation with all PCBs, while only PCB 180 and 170 had a negative correlation with waist cicumference and fat mass percentage in males. When the abdominal fat distribution was analysed in more detail, a significant negative correlation between the PCBs and abdominal fat was determined to be almost solely due to subcutaneous fat mass. In contrast, the positive correlation of $\beta \mathrm{HCH}$ in serum was observed regardless of adipose tissue distribution and localization (Dirinck et al. 2011). While no tissue samples were taken to directly measure POP levels in adipose tissue depots, these results indicate a correlation between obesity and serum POP levels and highlight sex differences in adipose tissue localization and serum POP levels.

Herein, it should be stated that BMI is the most commonly used method to characterize obesity and is routinely applied in estimating body fat (adiposity), yet this method is inaccurate when based solely on weight and height, excluding total body fat. In addition, BMI provides little to no information on overall health status or disease severity, cannot be generalized among different ethnic groups or sex, and is especially inaccurate in subjects with lean body mass (WHO 2000, Green \& Duffull 2004, Whyte et al. 2014). The limitations of BMI as a risk assessment tool are recognized, and there is continuing interest in identifying substitute or complementary indicators linking adiposity and disease risk. For example, visceral adiposity plays a key role in the metabolic disorders associated with obesity, yet the lack of a practical method to assess visceral fat in routine examinations precludes its use as a screening tool for the general population. Developing simple and reliable methods to assess body fat compartments should be an important priority of obesity research (Caballero 2007).

A common source of lipophilic POP exposure in humans is the consumption of fish, especially fatty fish such as salmon. In an effort to directly test the accumulation of POPs from dietary consumption and downstream effects on insulin resistance and metabolism, Ruzzin et al. (2010) investigated various high-fat diets in rats. Male rats were fed a high-fat diet of crude salmon oil (HFC) containing high levels of POPs or refined salmon oil (HFR) with significantly lower POP levels. After 28 days, rats fed on the HFC had significantly higher concentrations of VAT or abdominal obesity, and elevated levels of diacylglycerol, triacylglycerol, and total cholesterol compared with the HFR rats. Moreover, HFC-fed rats developed insulin resistance, impaired lipid and glucose metabolism, and hepatosteatosis, confirming that chronic exposure to POPs severely impairs insulin sensitivity and contributes to abdominal obesity in male rats (Ruzzin et al. 2010). Parallel studies in female rats were not performed, thus the effects of estrogens and potential sex-specific consequences of this study are unknown. In this same study, in vitro exposure of adipocytes to a cocktail of POPs showed a significant inhibition of insulin-dependent glucose uptake, providing further evidence of the risk of insulin resistance and metabolic disorders associated with the ingestion of POPs.

POPs have been shown to cause metabolic disruption. The study by Pestana and colleagues focused on assessing the association between POPs and this imbalance. VAT and SAT adipose tissue were collected from obese ( $>35 \mathrm{BMI})$ bariatric surgery patients $(n=189)$ of whom 166 were females, and tested them for 13 POPs (Pestana et al. 2014). Higher concentrations of POPs were found in VAT; however, detectable quantities of all compounds were found in virtually all patients. VAT acts as a highly metabolic active tissue with susceptibility to lipolysis and thereby causes POP release (Roos et al. 2013). Metabolic syndrome was found in $65.8 \%$ of the cohorts and, in this subset, total level of POPs in both VAT and SAT was higher.

Published by Bioscientifica Ltd 
Notably, the researchers found that the metabolic abnormalities had a correlation with dysglycemia, high blood pressure, and cardiovascular risk (Pestana et al. 2014). This study highlights the link between obesity and dysregulated adipose tissue due to POP exposure, underlining the need for more research into the mechanisms behind the dysregulation.

\section{POPs, obesity, and breast cancer}

Obesity-driven changes in the normal and cancerous breast microenvironment, alterations in metabolism, and release of signaling molecules such as endocrine, growth, and inflammatory mediators are known to increase breast cancer risk as well as promote breast cancer progression (Harvey et al. 2011, Sundaram et al. 2013, Nalabolu et al. 2014). However, studies investigating a direct mechanistic link among breast cancer, POP accumulation, and obesity are remarkably lacking despite the strong correlation between POPs, obesity, and disease (Prieto-Hontoria et al. 2011, Taylor et al. 2013, Zeliger 2013a,b).

While a correlation between high levels of POPs and breast cancer indicates that POPs may be a risk factor for breast cancer (Warner et al. 2002, Cabaravdic 2006, Lemaire et al. 2006, Bonefeld-Jorgensen et al. 2011), a direct relationship and corresponding biochemical mechanisms remain relatively undefined. The majority of associations between POPs and breast cancer risk have been attributed to the estrogenic effects of particular POPs on breast lesions. Basal-like tumors are characterized by lack of ER (ESR1) expression, an expression signature similar to the basal/myoepithelium, and are reported to have characteristics similar to those tumors arising from $B R C A 1$ germline mutation carriers. They are unresponsive to endocrine-targeted therapies such as tamoxifen and aromatase inhibitors and are associated with almost twice the risk of death when compared with ER-positive tumors (Dunnwald et al. 2007). Whether POPs affect both ER-positive and ER-negative breast cancer subtypes needs further investigation. In an attempt to address the effects of POPs on breast cancer cell proliferation, Aube et al. (2011) exposed four breast cancer cell lines to a cocktail of 15 different organochlorine compounds frequently found in the serum of women all around the world. ER-positive MCF7, T47D, and CAMA-1, and the ER-negative MDAMB231 were tested. These results indicate that the nonhormone-dependent MDA-MB231 cell line had decreased proliferation in the presence of the OC cocktail, and ER-positive T47D cells had no response. Low levels of exposure to the OC cocktail induced significant proliferation in the MCF7 cells, while high levels were inhibitory (Aube et al. 2011). The OC cocktail also had the capacity to stimulate the proliferation of CAMA-1 cells; however, this was only in the presence of exogenous $17 \beta$ estradiol and dihydrotestosterone. Clearly, more research is needed in order to understand these results and their potential clinical implications. Defining the effects of POPs on the various breast cancer subtypes has never been directly addressed, but is critical to fully determine whether POPs differentially influence the behavior or promotion of various breast cancer subtypes.

A comprehensive report focused on estrogen receptor tested 49 POPs for ER $\alpha$ and $\beta$ (ER $\alpha / \mathrm{ER} \beta)$ activation or inhibition via transfection of a luciferase-based reporter construct in HeLa cells (Lemaire et al. 2006). Fifteen of the POPs tested stimulated ER $\alpha$-mediated transcription in a dose-dependent manner, and five were capable of activating ER $\beta$. Antagonistic activities toward $\operatorname{ER} \alpha$ and $\operatorname{ER} \beta$ were also observed for select POPs. Most interestingly, chlordecone and methoxychlor, the most effective antagonist compounds for ER $\beta$, were strong agonists for ER $\alpha$. These results underscore the complexity of POP activation of ER signaling. Although the ER activation potential of POPs was documented in reporter assays, the results were not confirmed in breast cancer cells and the effects of these POPs on cell behavior were not investigated (Lemaire $e t$ al . 2006). In another study, the effects of the POP DDT and its metabolites on ER $\alpha$-expressing MCF7 and ER $\alpha$-negative MDA-MB231 cell lines were investigated. Notably, the POPs tested had strong opposing effects on the two cell lines, with the invasive potential of the MCF7 cells increased while the invasion of MDA-MB-231 cells was significantly reduced (Lemaire et al. 2006). While the estrogenic effects of POPs on breast cancer cells are apparent, the POPs induced inflammatory microenvironment and their paracrine effects on ER-negative or any breast cancer subtype remain to be defined.

A study published in 2011 focused on the observation that California has some of the highest breast cancer rates in the world, and some of the highest body burden levels of polybrominated diphenyl ethers (PBDE; flame retardants common in plastics, electronics and building materials), with levels approximately tenfold higher than those reported among European and Asian populations. The authors postulated that the estrogenic effects of PBDE might influence breast cancer risk (Petreas et al. 2011). Breast biopsies of women from the San Francisco Bay area were analyzed for five major PBDE congeners. Results indicated that elevated BDE-154 was associated with increased breast cancer risk, but the sample size was limited.

Published by Bioscientifica Ltd. 
Overall, the results provided no significant evidence of an association between breast tissue concentrations of PBDE and breast cancer risk, though the breast tissue levels of PBDE were the highest ever reported. Study limitations were a significant factor, including firstly, that the levels of PBDEs were measured at/around the time of diagnosis and therefore may not have been representative of lifetime exposures or exposures during potentially critical windows of susceptibility during earlier life. Secondly, the control group included women with proliferative benign breast lesions and evidence indicates these women are at an increased risk for breast cancer (Schnitt 2001, Collins et al. 2006, Aroner et al. 2010). Thirdly, PBDE levels are inversely correlated with age and recruitment resulted in a skewed age distribution such that controls were significantly younger than cases. Moreover, it is of note that out of the 78 cases and 56 controls only a total of seven women had a BMI over 30. As presented herein, high BMI combined with POPs is a factor worthy of investigation, but not adequately represented by this cohort (Petreas et al. 2011).

Until the 1970s, the Inuit population of Greenland and Canada had one of the lowest breast cancer rates in the world. No cases were reported before 1967; however, a surge of 193 cases was reported between 1969 and 1997 (Nielsen \& Hansen 1980, Bonefeld-Jorgensen et al. 2011, 2014). Congruently, the Inuit population exhibited some the highest serum concentrations of POPs globally. This bioaccumulation has been proposed to be a direct result from the high dietary consumption of fats from fish, seal, whale, polar bear, and seabirds leading researchers to propose the theory that the high concentration of POPs found within tissues was related to the recent increase in the number of breast cancer cases (Bonefeld-Jorgensen et al. 2014). To further investigate, serum levels of breast cancer patients were analyzed for POPs between 2000 and 2003. Results indicated significantly higher levels of perfluorinated compounds (PFCs), as well as double the median level of PFOS and sum of perfluorosulfonate acids (sumPFSAs) in breast cancer patients compared with controls. No difference was observed in the serum levels of OCPs and PCBs. However, when PCBs were subdivided, significantly higher concentrations were observed in the highest quartiles. Collectively, these results indicate that high levels of POPs are directly related to increased breast cancer rates in the Inuit population. As studies continue to show increasing concentrations of select POPs in arctic mammals and fish, it is critical to understand the molecular mechanism contributing to cancer risk or progression to provide better guidelines for targeted therapies and preventative measures (Butt et al. 2010, Letcher et al. 2010, Sonne 2010).
In the past decade, the role of the cancer microenvironment has come to the forefront of research. It is now well documented that the surrounding stromal cells, including adipocytes, fibroblasts, immune, and endothelial cells, have a significant effect on breast cancer progression (CasbasHernandez et al. 2011, Sundaram et al. 2013). As the majority of breast tissue is adipose tissue, and numerous reports have shown dramatic effects of POPs on the adipose tissue, coculture studies observing the direct effects of POPs on adipocytes and subsequent paracrine effects on breast cancer cell behavior are necessary. Ex vivo studies using breast cancer cell cocultures with adipocytes are an excellent starting point for comprehensive paracrine studies of the influence of POPs on cancer cell behavior. Salameh et al. (2013) isolated rat mammary fat pads, devoid of epithelium, and cultured these glands in vitro. The cultured tissues were administered CRL1743 rat mammary tumor epithelial cells by injection and their migration and tumorigenesis were documented. Results obtained using coherent anti-Stokes Raman scattering (CARS) microscopy indicated that the morphological outgrowths mimicked cancer cell morphology in vivo and highlighted the potential for future studies. This model also provides a platform for development of paracrine cell interaction studies investigating the effects of POP incorporation during various metabolic states (i.e., high-fat/western diet vs low-fat diet). A second 3D model system, similar to a skin culture system, was used to demonstrate the interactions among preadipocytes, adipocytes, fibroblasts, and breast cancer cells (Delort et al. 2013). Contact with breast cancer cells enhanced the differentiation of preadipocytes into adipocytes, and completely modified their transcriptional programs by increasing the expression of genes involved in cell proliferation (cyclin D1 and MAPK), angiogenesis (MMP9 and $V E G F)$, and hormonal signaling (ESR1 and IL6). Moreover, another 3D model of differentiated T3T-L1 adipocytes with normal murine mammary epithelial cells was used to demonstrate that adipocyte-rich stroma induces branching through paracrine signals, including hepatocyte growth factor secretion, and this may serve as a good model for studies during pubertal development (Pavlovich et al. 2010). The addition of POPs could reveal potential alterations in branching morphogenesis or initiation of pre-cancerous lesions during puberty. This issue is imperative as it directly relates to contemporary issues involving childhood obesity and cancer risk later in life.

Serum levels of leptin, a key modulator involved in regulating energy intake and expenditure, are increased in breast cancer patients and have been implicated in the association between high BMI and breast cancer risk

Published by Bioscientifica Ltd. 
(Romero-Figueroa Mdel et al. 2013). Leptin also transactivates key breast-cancer-promoting targets, including HER2, ER $\alpha$, EGFR, and IGF1 receptors. Notably, correlations between POPs and leptin dysregulation are strong (Saxena et al. 2008, Pereira-Fernandes et al. 2014). PFOS, which is among the degradation product of many perfluorinated POPs, was fed to maternal rats and the effects of ingestion on the offspring in adulthood were investigated (Lv et al. 2013). During gestation and lactation, offspring were indirectly exposed to $0.5 \mathrm{mg} / \mathrm{kg}$ per day or $1.5 \mathrm{mg} / \mathrm{kg}$ per day PFOS, respectively, from gestation day 0 to postnatal day 21 . The offspring exhibited low body weight until weaning and displayed signs of a prediabetic state including elevated fasting serum leptin levels, elevated insulin, and impaired glucose tolerance, regardless of exposure levels. These results indicated that developmental exposure to PFOS may contribute to glucose and lipid metabolic disorders in adulthood.

Further highlighting the potential differences in effects between sexes, a clinical-based analysis of adipose tissue depots with POP accumulation found a significant correlation between high serum leptin concentrations and several PCBs in women, whereas no correlations were found between (Pereira-Fernandes et al. 2014). Though breast tissue was not analyzed, in visceral fat a significant correlation was found between leptin, POPs, and obesity in women. Leptin gene expression was also positively correlated with levels of key POPs, such as CB180 and BDE153. These results indicate a potential interaction between POPs and leptin signaling; however, definitive studies testing whether circulating POPs disrupt leptin signaling are yet to be performed. Further extension of these observations on changes in leptin levels in response to POPs to the question of whether or not they influence breast cancer tumorigenesis also has yet to be performed.

POP levels are exponentially higher in adipose tissue among obese subjects than in normal-weight subjects (Airaksinen et al. 2011), and obesity causes adipose tissue to become inflamed, thus leading to dysfunction (PrietoHontoria et al. 2011). POP exposure and bioaccumulation in tissue also promotes dysregulation of adipokines, including adiponectin (Kim et al. 2010, Pereira-Fernandes et al. 2014). For example, adiponectin expression in VAT correlated negatively with levels of the PCB congener CB138, indicating that POPs could have an influence on obesityrelated disorders by suppressing the expression of adiponectin, a protective adipokine (Pereira-Fernandes et al. 2014). Results of another study revealed the effects of another PCB congener, CB77, on the suppression of adiponectin expression of mature adipocytes in vitro
(Arsenescu et al. 2008). Furthermore, in overweight and obese subjects, adiponectin is downregulated and inversely associated with levels of sex steroids (Duggan et al. 2011), all of which are markers of an increased risk of breast cancer in pre- and postmenopausal women. Whether POPs stimulate a decrease in adiponectin specifically in breast tissue is unknown, and the direct relationship between POP exposure driving a reduction in adiponectin and the subsequent effects on breast cancer cell behavior has not been investigated. However, adiponectin inhibits important metastatic properties such as adhesion, invasion, and migration of breast cancer cells. Consequently, breast tumors arising in a low-adiponectin environment are associated with a more aggressive phenotype (Saxena \& Sharma 2010, Hwang et al. 2013). Thus, further investigation as to whether POPs would stimulate more aggressive breast cancer subtypes via suppression of adiponectin is warranted.

Conversely, a recent study by Salisbury et al. (2013) implicated an inverse correlation between POPs and breast cancer incidence in the binding and activation of the aryl hydrocarbon receptor (AhR) (Salisbury et al. 2013). AhR is a diverse transcription factor involved in regulating xenobiotic metabolism as well as genes relevant to obesity and inflammation (Beischlag et al. 2008, Bourdon et al. 2010, Kerley-Hamilton et al. 2012, La Merrill et al. 2013, Myre \& Imbeault 2014). The AhR affects signaling pathways including the retinoic acid receptor, $\mathrm{ER}$, and the NFKB (Beischlag et al. 2008). In their study, AhR signaling activation-enhanced proliferation of ER-positive breast cancer cell lines (MCF7 and T47D) via IGF2-containing adipocyte-conditioned media. Conversely, 2,3,7,8-tetrachlorodibenzo-p-dioxin (TCDD), a highly specific AhR agonist and POP, blocked IGF2 signaling and cell proliferation (Salisbury et al. 2013), indicating that select POPs in the local microenvironment may inhibit cancer cell growth via activation of AhR. However, the paracrine effects of POPs in the tissue microenvironment must be investigated in combination with tumor cell growth. Results from a study using human multipotent adipose-tissue-derived stem cells indicated that exposure to the AhR ligands TCDD and PCB congener 126 significantly regulated genes involved in inflammatory/immune response, cancer, and metabolic pathways (Kim et al. 2012). This was observed in both precursor cells and adipocytes, and it was demonstrated that AhR activation was the major pathway inducing these changes by inhibition of AhR using the AhR antagonist $\alpha$-naphthoflavone. Regulation of the inflammatory pathway via TCDD and PCB-126 was also observed in WT but not Ahr-knockout mice. While the paracrine effect of the adipose tissue on tumor cells was not examined directly,

Published by Bioscientifica Ltd. 
the pathways activated in the precursor and adipose cells indicate potential augmentation of tumorigenesis.

Another potential mechanism of action for POPs and obesity on breast tumorigenesis is through the action of fatty acid synthase (FASN), an enzyme responsible for producing endogenous fatty acids. This enzyme has been shown to be necessary for proliferation and survival effects of numerous malignant cancers, promoting tumor aggression (Puig et al. 2009). With regard to breast cancer specifically, it has been demonstrated that there are significantly elevated levels of FASN in vitro and in vivo, and this enhanced expression has been directly correlated with enhanced aggressive breast cancer cell behaviors, enhanced tumor progression, and poor prognosis (Hunt etal. 2007, Hilvo etal. 2011, Hopperton et al. 2014, Khan et al. 2014). FASN is also linked to the accumulation of visceral fat, the development of type 2 diabetes, and obesity (Berndt et al. 2007). Obesity generates free fatty acids that in turn elevate tissue levels of FASN and increase de novo lipogenesis by cancer cells (Hunt et al. 2007). The observation of this cycle highlights a molecular mechanism by which obesity can drive breast cancer. To tie in POPs with this mechanism, we highlight a study focused on determining whether the antioxidant glutathione was important in protecting liver tissue from TCDD-mediated toxicity and development of non-alcoholic fatty liver disease with associated steatosis (Chen et al. 2012). Results indicate that TCDD stimulates liver toxicity and altered lipid metabolism via several lipid metabolism genes, including FASN. G $\mathrm{clm}^{-1-}$ knockout mice, a model of liver glutathione deficiency, were protected from liver steatosis and correspondingly had significantly decreased FASN expression levels. These results indicate that altered lipid metabolism, in part by FASN function, is induced via the POP TCDD. It would be of interest to determine whether POPs similarly function in part through FASN to alter lipid metabolism in breast tissue, thereby potentially promoting breast tumorigenesis.

Lifetime exposure to POPs through dietary intake would, over time, result in continual increases in bioaccumulation in adipose tissue due to the lipophilic nature of POPs. It is also of note that age is the most significant risk factor for development of breast cancer (Carriot et al. 2014). It could be hypothesized that bioaccumulation of POPs with age could additively/ synergistically promote breast cancer progression. A collective interaction of inflammation with altered local hormone production and altered immune function has been observed with age (Chung et al. 2008, Priyanka et al. 2013). In postmenopausal women, a significant amount of estrogen is supplied by adipose tissue (Huang et al. 1997).
By adding a lifetime exposure to POPs, bioaccumulation in adipose tissue could have severe consequences, potentially further compounded by obesity. It is important to ward off this increased risk as $70 \%$ of breast cancers are estrogenreceptor-positive and higher levels of estrogen increase the risk (Carriot et al. 2014, Santen et al. 2014).

\section{Socioeconomic impact of POPs and breast cancer}

Results from multiple epidemiological studies indicate a worse prognosis for women who are obese at the time of breast cancer diagnosis compared with non-obese patients (Protani et al. 2010). Results presented in a meta-analysis of 43 studies of obesity and breast cancer revealed that obese patients were 33\% more likely than non-obese patients to die of breast cancer (Protani et al. 2010). Socioeconomic status has been classically known to affect diet, with a low level of education, moderate level of physical activity, and cost per calorie identified as important mediators in the socioeconomic status-BMI relationship (Fokeena \& Jeewon 2012, Dunneram \& Jeewon 2013). Previously reported trends have included an increase in BMI and metabolic syndrome in the populations with higher socioeconomic status among developing countries (Caballero 2007). However the influence of socioeconomic status on obesity has been shifting, affecting a broader range of societies, and is suggested to be due to increased consumption of sweetened beverages, and increased availability of lowcost, energy-dense foods in urban areas of developing countries (Caballero 2007). Results from recent studies demonstrate that the problem of obesity is increasing among middle-aged (Caballero 2007, Dunneram \& Jeewon 2013) and postmenopausal women (Caballero 2007, Bhurosy \& Jeewon 2013) and adolescents of low socioeconomic status in middle-income countries in Africa, as well as urban and rural areas in the poorest countries of sub-Saharan Africa and South Asia and in countries with higher levels of income (Popkin et al. 2012, Bhurosy \& Jeewon 2014). Similarly, as part of another socioeconomic study across 22 western European countries it was reported that obesity (BMI > 30) was more common among women of lower education level (Mackenbach et al. 2008).

With respect to breast cancer mortality, AfricanAmerican women suffer disproportionately compared with other racial/ethnic groups (Newman et al. 2002, Jemal et al. 2007, DeSantis et al. 2014) and this has been related to their increased prevalence of high-fat/poor diet, obesity, and metabolic syndrome. Both social and

Published by Bioscientifica Ltd 
biological mechanisms are contributory, including a higher prevalence of aggressive basal-like, 'triple-negative' breast cancers in young, premenopausal African-American women (Boyle 2012). This subtype does not express detectable levels of ER and PR and does not overexpress the growth factor Her2. Therefore, this subtype is deemed to be unresponsive to anti-estrogenic compounds and, currently, no effective targeted therapies exist, and patient survival is poor (Sorlie et al. 2001). Even when AfricanAmerican women (of any age) are diagnosed with 'good prognosis' luminal A breast cancers, they fare worse than Caucasian women with the same subtype (Murray et al. 2010). Correspondingly, the prevalence of metabolic syndrome is higher among luminal breast cancers in postmenopausal women (OR 1.37 (95\% CI 1.07-2.80) $P=0.03$ ) and, most notably, BMI alone was associated with luminal A subtype breast cancer risk (OR 1.12 (95\% CI 0.96-2.196) $P=0.2$ ) (Capasso et al. 2014). Unfortunately, race was not addressed in this study.

Results of research on social disparities indicate the percentage of POPs to be at its highest in women without a formal education and at its lowest in affluent women (Freire et al. 2011, Arrebola et al. 2013, Gasull et al. 2013, Wilcox et al. 2013). In low socioeconomic ethnic-based communities, the availability of healthy food is inconsistent at best. Fresh fruits and vegetables are somewhat non-existent or too expensive to feed a family. A poor diet of processed/fast foods and fatty meats all contribute to the obesity epidemic prevalent in the African-American community increasing their susceptibility to hypertension, cardiovascular disease, diabetes, and obesity (Caprio et al. 2008a,b, Hebert et al. 2013, Wilcox et al. 2013). In a study by Chandran et al. (2012), African-American women were shown to be less physically active, overweight, or obese, and have a higher intake of total cholesterol and fat than women of other ethnicities (Chandran et al. 2012). In addition to dietary choices and food availability, a multitude of factors influence the observed disparities in obesity. For example, a study involving the Jackson Heart Study participants $(n=2881)$ reported that travel for healthier food options was inhibited due to safety concerns and perceived neighborhood safety (Pham do et al. 2014). AfricanAmerican women who strongly disagreed that their neighborhood was safe from crime had a higher BMI compared with women who felt safe, and premenopausal African-American women who felt most unsafe had significantly higher BMI, waist circumference, and volumes of visceral and total adipose tissue than those who felt safe (Pham do et al. 2014). These data highlight that, in addition to dietary factors, emotional stress may play a role in the promotion of obesity in these communities. It has also been shown that African-American women have a higher burden of PCDD/PCDFs compared with other ethnicities (Reynolds et al. 2005). These women do not have a higher incidence of breast cancer but, more importantly, they have the worst prognosis and survival rates (Chandran et al. 2012). If it is true that lower socioeconomic classes have higher levels of POPs and POPs accumulate in adipose tissue, then it can be suggested that the poor prognosis of African-American women with breast cancer could be attributed to the level of POPs in their adipose tissue.

\section{Model systems}

To study breast development, dysregulation, and cancer, mouse and rat animal models are frequently used. Numerous murine models have been developed to study normal human breast development and cancer, including the most widely used human xenograft models. In these models, human breast epithelium, stromal, and/or tumor cells are transplanted orthotopically into immunocompromised mice that do not reject human cells (Proia \& Kuperwasser 2006, Richmond \& Su 2008). The threedimensional tissue organization, whole-body metabolism, and hormone and growth factor interactions are a highlighted benefit for understanding postpubertal breast development and function compared with limited in vitro coculture studies. However, significant limitations include cross-species complications regarding signaling molecules and the lack of immune cell interactions, a known critical component of tumorigenesis and progression. Knockout mouse models are useful for studying the effects of a single gene during disease. Two knockout mouse models have been used to study the effects of POPs in vivo, though we were unable to find any studies involving mammary function and POP interactions. The Ahr-knockout mouse model has been used to test the effects of TCDD on epididymal adipose tissue compared with WT controls. Male mice were treated with a non-acute toxic dose of TCDD and results demonstrated that preadipocytes and adipocytes are targets of POPs and that one of the main pathways activated was inflammation. Activation of the inflammatory pathways was not observed in Ahr-knockout mice, thus using this model it was demonstrated that a major pathway of TCDD is via AhR activation (Kim et al. 2012). The $A p o e^{-/-}$mouse model has also been used to study POPs in vivo, confirming, or highlighting, the synergistic effects of POPs on atherosclerosis (Conklin et al. 2010, Shan et al. 2014). Another category of models for studying human breast cancer are genetically engineered

Published by Bioscientifica Ltd. 
mouse (GEM) models, in which mice carry the same mutation within the endogenous locus, and the gene is expressed within the specific cell types that occur in human tumors and is silent during embryogenesis (Shoushtari et al. 2007). Although knockout and GEM models are highly useful for evaluating the effects of specific mutation, deletion, or gene amplification of one or two genes during breast or tumor progression, they usually cannot fully reproduce the genetic complexity of human tumors. However, it cannot be denied that many advances have been made using results obtained from these models and they will continue to provide valuable data to the field.

Potentially, one of the most significant limitations of using mouse models is the morphological and structural differences among the epithelium and stroma in murine fat pads compared with human breast. The mouse mammary gland contains large depots of adipose tissue laced with small amounts of interspersed connective tissue (Parmar \& Cunha 2004). The functional lobular units of the mouse gland are embedded within the fat pad and have a considerable amount of space between the minimally branched ducts. In contrast, the lobular units of the human breast are surrounded by loose intralobular connective tissue, consisting primarily of fibroblasts. This intralobular stroma is subsequently surrounded by a more compact interlobular stroma, which isolates the lobules and intralobular stroma from any substantial direct contact with the adipose tissue (Fleming et al. 2008). Thus, alterations in breast cellular communication in response to obesity in humans compared with mice may substantially vary, given the differences in amount and proximity of the adipose tissue to the epithelium. Stemming from the observations that these stromal subtypes differ in their physical location in relation to epithelial lobules, and that epithelial/stromal interactions can promote or inhibit tumorigenesis, animal models that better resemble human breast structure are critically needed for performing experimental studies investigating collective metabolic, developmental, and environmental interactions.

Rats have been highlighted as a more appropriate model due to the similarities in ductal and lobular mammary structures, spatial proximity to fibroblasts and adipose tissue, total adipose tissue content, as well as hormone and paracrine cell interactions (Shepel \& Gould 1999, VargoGogola \& Rosen 2007). One slight developmental variation in rats is a constant growth of lobular and ductal structures

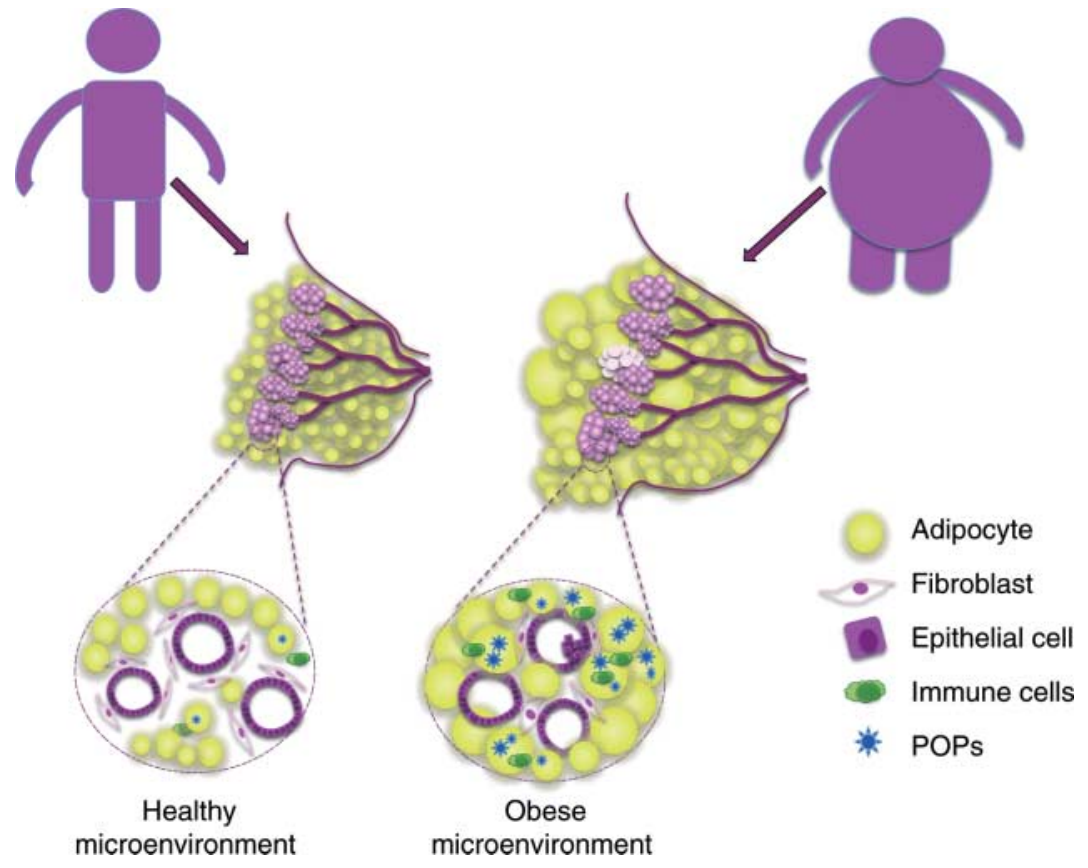

\section{Figure 1}

Potential mechanisms for the involvement of POPs in the promotion of breast cancer. Obesity-associated endocrine and metabolic mediators are suspected to play a role in oncogenesis by modifying both systemic nutrient metabolism and the nutrients available locally in the supportive stromal tissue. Excessive amounts of adipose tissue in obese women also serve as
(C) 2015 Society for Endocrinology Printed in Great Britain storage depots for POPs obtained from dietary sources. The accumulated POPs stimulate additional adipocyte proliferation and recruitment of immune cells, leading to an inflammatory microenvironment. Collectively, these factors may promote breast cancer development and/or direct cancer cell phenotypes.

Published by Bioscientifica Ltd. 
into the adipose tissue; human lobular structures do not extend into fat tissue and ductal structures grow along connective tissue septa (Russo 1983, Russo et al. 1990). However, a significant advantage of using rat models is the close association of rat and human breast cancer genes and risk alleles (Sanders \& Samuelson 2014). Moreover, in contrast to mouse models, chemically induced rat mammary tumors are generally hormone-dependent adenocarcinomas. For this reason, rat mammary carcinogenesis models have been utilized extensively to investigate hormone-dependent breast cancer and the protective role of pregnancy in breast cancer (Vargo-Gogola \& Rosen 2007). Rat models are also popular for metabolic and nutritional studies, and historically chemically induced tumors have been evaluated in correlation with dietinduced obesity. Collectively, these studies have shown that 7,12, dimethylbenz[a]anthracene (DMBA) and $\mathrm{N}$-nitrosomethylurea (NMU)-induced mammary tumors had enhanced proliferation in obese rats compared with normal-weight controls (Chan et al. 1977, Hakkak et al. 2005, 2007, Lautenbach et al. 2009). It is of note that the more relevant studies to human health and breast cancer, such as those of dietary POP accumulation, the contribution of POPs to obesity, and mammary adipose/ stromal tissue function together with mammary cancers have not been studied in the rat model.

\section{Conclusions}

In conclusion, results from numerous correlative studies indicate a strong association between POP exposure through diet and the bioaccumulation of POPs in adipose tissue, which promotes the development of obesity and ultimately influences breast cancer development and/or progression (Fig. 1). There is a critical need for advanced model systems and pioneering in vitro and in vivo studies to elucidate the complex relationship between these causative factors and, more importantly, to delineate their multifaceted molecular, cellular, and biochemical mechanisms.

\section{Declaration of interest}

The authors declare that there is no conflict of interest that could be perceived as prejudicing the impartiality of this review.

\section{Funding}

This work was supported by funding from the National Cancer Institute (U54 CA156735 and R21 CA175783) and the National Institute of General Medical Sciences (SC2 GM102012). This work was supported in part by the Intramural Research Program of the $\mathrm{NIH}, \mathrm{NCl}$.

\section{References}

Agudo A, Goni F, Etxeandia A, Vives A, Millan E, Lopez R, Amiano P, Ardanaz E, Barricarte A, Chirlaque MD et al. 2009 Polychlorinated biphenyls in Spanish adults: determinants of serum concentrations. Environmental Research 109 620-628. (doi:10.1016/j.envres.2009.03.009)

Airaksinen R, Rantakokko P, Eriksson JG, Blomstedt P, Kajantie E \& Kiviranta H 2011 Association between type 2 diabetes and exposure to persistent organic pollutants. Diabetes Care 34 1972-1979. (doi:10.2337/dc10-2303)

Aroner SA, Collins LC, Schnitt SJ, Connolly JL, Colditz GA \& Tamimi RM 2010 Columnar cell lesions and subsequent breast cancer risk: a nested case-control study. Breast Cancer Research 12 R61. (doi:10.1186/ bcr2624)

Arrebola JP, Pumarega J, Gasull M, Fernandez MF, Martin-Olmedo P, Molina-Molina JM, Fernandez-Rodriguez M, Porta M \& Olea N 2013 Adipose tissue concentrations of persistent organic pollutants and prevalence of type 2 diabetes in adults from Southern Spain. Environmental Research 122 31-37. (doi:10.1016/j.envres.2012.12.001)

Arsenescu V, Arsenescu RI, King V, Swanson H \& Cassis LA 2008 Polychlorinated biphenyl-77 induces adipocyte differentiation and proinflammatory adipokines and promotes obesity and atherosclerosis. Environmental Health Perspectives 116 761-768. (doi:10.1289/ehp. 10554)

Aube M, Larochelle C \& Ayotte P 2011 Differential effects of a complex organochlorine mixture on the proliferation of breast cancer cell lines. Environmental Research 111337-347. (doi:10.1016/j.envres.2011.01.010)

Baillie-Hamilton PF 2002 Chemical toxins: a hypothesis to explain the global obesity epidemic. Journal of Alternative and Complementary Medicine 8 185-192. (doi:10.1089/107555302317371479)

Barber MC, Clegg RA, Travers MT \& Vernon RG 1997 Lipid metabolism in the lactating mammary gland. Biochimica et Biophysica Acta 1347 101-126. (doi:10.1016/S0005-2760(97)00079-9)

Baumann J, Sevinsky C \& Conklin DS 2013 Lipid biology of breast cancer. Biochimica et Biophysica Acta 1831 1509-1517. (doi:10.1016/j.bbalip. 2013.03.011)

Beischlag TV, Luis Morales J, Hollingshead BD \& Perdew GH 2008 The aryl hydrocarbon receptor complex and the control of gene expression. Critical Reviews in Eukaryotic Gene Expression 18 207-250. (doi:10.1615/ CritRevEukarGeneExpr.v18.i3.20)

Berndt J, Kovacs P, Ruschke K, Kloting N, Fasshauer M, Schon MR, Korner A, Stumvoll M \& Bluher M 2007 Fatty acid synthase gene expression in human adipose tissue: association with obesity and type 2 diabetes. Diabetologia 50 1472-1480. (doi:10.1007/s00125-007-0689-x)

Bhurosy T \& Jeewon R 2013 Food habits, socioeconomic status and body mass index among premenopausal and post-menopausal women in Mauritius. Journal of Human Nutrition and Dietetics 26 (Suppl 1) 114-122. (doi:10.1111/jhn.12100)

Bhurosy T \& Jeewon R 2014 Overweight and obesity epidemic in developing countries: a problem with diet, physical activity, or socioeconomic status? ScientificWorldJournal 2014964236. (doi:10.1155/2014/964236)

Bloor ID \& Symonds ME 2014 Sexual dimorphism in white and brown adipose tissue with obesity and inflammation. Hormones and Behavior 66 95-103. (doi:10.1016/j.yhbeh.2014.02.007)

Bonefeld-Jorgensen EC, Long M, Bossi R, Ayotte P, Asmund G, Kruger T, Ghisari M, Mulvad G, Kern P, Nzulumiki P et al. 2011 Perfluorinated compounds are related to breast cancer risk in Greenlandic Inuit: a case control study. Environmental Health 10 88. (doi:10.1186/1476069X-10-88)

Bonefeld-Jørgensen EC, Ghisari M, Wielsøe M, Bjerregaard-Olesen C, Kjeldsen LS \& Long M 2014 Biomonitoring and hormone-disrupting effect biomarkers of persistent organic pollutants in vitro and ex vivo. Basic \& Clinical Pharmacology \& Toxicology 115 118-128. (doi:10.1111/ bcpt.12263)

Published by Bioscientifica Ltd. 
Bourdon JA, Bazinet TM, Arnason TT, Kimpe LE, Blais JM \& White PA 2010 Polychlorinated biphenyls (PCBs) contamination and aryl hydrocarbon receptor (AhR) agonist activity of Omega-3 polyunsaturated fatty acid supplements: implications for daily intake of dioxins and PCBs. Food and Chemical Toxicology 48 3093-3097. (doi:10.1016/j.fct.2010.07.051)

Bourez S, Le Lay S, Van den Daelen C, Louis C, Larondelle Y, Thome JP, Schneider YJ, Dugail I \& Debier C 2012 Accumulation of polychlorinated biphenyls in adipocytes: selective targeting to lipid droplets and role of caveolin-1. PLoS ONE 7 e31834. (doi:10.1371/journal.pone.0031834)

Bourez S, Van den Daelen C, Le Lay S, Poupaert J, Larondelle Y, Thome JP, Schneider YJ, Dugail I \& Debier C 2013 The dynamics of accumulation of PCBs in cultured adipocytes vary with the cell lipid content and the lipophilicity of the congener. Toxicology Letters 216 40-46. (doi:10.1016/j.toxlet.2012.09.027)

Boyle P 2012 Triple-negative breast cancer: epidemiological considerations and recommendations. Annals of Oncology 23 (Suppl 6) vi7-v12. (doi:10.1093/annonc/mds187)

van den Brandt PA, Spiegelman D, Yaun SS, Adami HO, Beeson L, Folsom AR, Fraser G, Goldbohm RA, Graham S, Kushi L et al. 2000 Pooled analysis of prospective cohort studies on height, weight, and breast cancer risk. American Journal of Epidemiology 152 514-527. (doi:10. 1093/aje/152.6.514)

Butt CM, Berger U, Bossi R \& Tomy GT 2010 Levels and trends of polyand perfluorinated compounds in the arctic environment. Science of the Total Environment 408 2936-2965. (doi:10.1016/j.scitotenv.2010. 03.015)

Caballero B 2007 The global epidemic of obesity: an overview. Epidemiologic Reviews 29 1-5. (doi:10.1093/epirev/mxm012)

Cabaravdic M 2006 Xenoestrogen effects of chemical compounds: influence on the breast cancer. Medical Archives 60 97-100.

Capasso I, Esposito E, de Laurentiis M, Maurea N, Cavalcanti E, Botti G, Petrillo A, Montella M, D'Aiuto M, Coppola C et al. 2014 Metabolic syndrome-breast cancer link varies by intrinsic molecular subtype. Diabetology \& Metabolic Syndrome 6 105. (doi:10.1186/1758-5996-6-105)

Caprio S, Daniels SR, Drewnowski A, Kaufman FR, Palinkas LA, Rosenbloom AL \& Schwimmer JB 2008a Influence of race, ethnicity, and culture on childhood obesity: implications for prevention and treatment. Obesity 16 2566-2577. (doi:10.1038/oby.2008.398)

Caprio S, Daniels SR, Drewnowski A, Kaufman FR, Palinkas LA, Rosenbloom AL \& Schwimmer JB $2008 b$ Influence of race, ethnicity, and culture on childhood obesity: implications for prevention and treatment: a consensus statement of Shaping America's Health and the Obesity Society. Diabetes Care 31 2211-2221. (doi:10.2337/dc08-9024)

Carriot J, Jamali M, Chacron MJ \& Cullen KE 2014 Statistics of the vestibular input experienced during natural self-motion: implications for neural processing. Journal of Neuroscience 34 8347-8357. (doi:10.1523/JNEUROSCI.0692-14.2014)

Casbas-Hernandez P, Fleming JM \& Troester MA 2011 Gene expression analysis of in vitro cocultures to study interactions between breast epithelium and stroma. Journal of Biomedicine \& Biotechnology 2011 520987. (doi:10.1155/2011/520987)

Casbas-Hernandez P, Sun X, Roman-Perez E, D'Arcy M, Sandhu R, Hishida A, McNaughton KK, Yang XR, Makowski L, Sherman ME et al. 2014 Tumor intrinsic subtype is reflected in cancer-adjacent tissue. Cancer Epidemiology, Biomarkers \& Prevention (In Press). (doi:10.1158/1055-9965.EPI-14-0934)

Chan PC, Head JF, Cohen LA \& Wynder EL 1977 Influence of dietary fat on the induction of mammary tumors by $N$-nitrosomethylurea: associated hormone changes and differences between Sprague-Dawley and F344 rats. Journal of the National Cancer Institute 59 1279-1283. (doi:10.1093/ jnci/59.4.1279)

Chandran U, Hirshfield KM \& Bandera EV 2012 The role of anthropometric and nutritional factors on breast cancer risk in African-American women. Public Health Nutrition 15 738-748. (doi:10.1017/ S136898001100303X)

Chen Y, Krishan M, Nebert DW \& Shertzer HG 2012 Glutathione-deficient mice are susceptible to TCDD-induced hepatocellular toxicity but resistant to steatosis. Chemical Research in Toxicology 25 94-100. (doi:10.1021/tx200242a)

Chung JH, Seo AY, Chung SW, Kim MK, Leeuwenburgh C, Yu BP \& Chung HY 2008 Molecular mechanism of PPAR in the regulation of age-related inflammation. Ageing Research Reviews 7 126-136. (doi:10.1016/j.arr. 2008.01.001)

Collins LC, Baer HJ, Tamimi RM, Connolly JL, Colditz GA \& Schnitt SJ 2006 The influence of family history on breast cancer risk in women with biopsy-confirmed benign breast disease: results from the Nurses' Health Study. Cancer 107 1240-1247. (doi:10.1002/cncr.22136)

Conklin DJ, Barski OA, Lesgards JF, Juvan P, Rezen T, Rozman D, Prough RA, Vladykovskaya E, Liu S, Srivastava S et al. 2010 Acrolein consumption induces systemic dyslipidemia and lipoprotein modification. Toxicology and Applied Pharmacology 243 1-12. (doi:10.1016/j.taap.2009.12.010)

Corsini E, Luebke RW, Germolec DR \& DeWitt JC 2014 Perfluorinated compounds: emerging POPs with potential immunotoxicity. Toxicology Letters 230 263-270. (doi:10.1016/j.toxlet.2014.01.038)

De Assis S \& Hilakivi-Clarke L 2006 Timing of dietary estrogenic exposures and breast cancer risk. Annals of the New York Academy of Sciences 1089 14-35. (doi:10.1196/annals.1386.039)

Decherf S \& Demeneix BA 2011 The obesogen hypothesis: a shift of focus from the periphery to the hypothalamus. Journal of Toxicology and Environmental Health. Part B, Critical Reviews 14 423-448. (doi:10.1080/ 10937404.2011.578561)

Delort L, Lequeux C, Dubois V, Dubouloz A, Billard H, Mojallal A, Damour O, Vasson MP \& Caldefie-Chezet F 2013 Reciprocal interactions between breast tumor and its adipose microenvironment based on a 3D adipose equivalent model. PLOS ONE 8 e66284. (doi:10.1371/journal.pone. 0066284)

De Pergola G \& Silvestris F 2013 Obesity as a major risk factor for cancer. Journal of Obesity 2013291546. (doi:10.1155/2013/291546)

DeSantis C, Ma J, Bryan L \& Jemal A 2014 Breast cancer statistics, 2013. CA: A Cancer Journal for Clinicians 64 52-62. (doi:10.3322/caac.21203)

DeWitt JC, Peden-Adams MM, Keller JM \& Germolec DR 2012 Immunotoxicity of perfluorinated compounds: recent developments. Toxicologic Pathology 40 300-311. (doi:10.1177/0192623311428473)

Dirinck E, Jorens PG, Covaci A, Geens T, Roosens L, Neels H, Mertens I \& Van Gaal L 2011 Obesity and persistent organic pollutants: possible obesogenic effect of organochlorine pesticides and polychlorinated biphenyls. Obesity 19 709-714. (doi:10.1038/oby.2010.133)

Domingo JL 2012 Health risks of dietary exposure to perfluorinated compounds. Environment International 40 187-195. (doi:10.1016/j. envint.2011.08.001)

Duggan C, Irwin ML, Xiao L, Henderson KD, Smith AW, Baumgartner RN, Baumgartner KB, Bernstein L, Ballard-Barbash R \& McTiernan A 2011 Associations of insulin resistance and adiponectin with mortality in women with breast cancer. Journal of Clinical Oncology 29 32-39. (doi:10.1200/JCO.2009.26.4473)

Dunneram Y \& Jeewon R 2013 A scientific assessment of sociodemographic factors, physical activity level, and nutritional knowledge as determinants of dietary quality among Indo-Mauritian women. Journal of Nutrition and Metabolism 2013 572132. (doi:10.1155/2013/572132)

Dunnwald LK, Rossing MA \& Li CI 2007 Hormone receptor status, tumor characteristics, and prognosis: a prospective cohort of breast cancer patients. Breast Cancer Research 9 R6. (doi:10.1186/bcr1639)

Fleming JM, Long EL, Ginsburg E, Gerscovich D, Meltzer PS \& Vonderhaar BK 2008 Interlobular and intralobular mammary stroma: genotype may not reflect phenotype. BMC Cell Biology 9 46. (doi:10.1186/14712121-9-46)

Fokeena WB \& Jeewon R 2012 Is there an association between socioeconomic status and body mass index among adolescents in Mauritius? ScientificWorldJournal 2012 750659. (doi:10.1100/2012/750659)

Freire C, Amaya E, Fernandez MF, Gonzalez-Galarzo MC, Ramos R, MolinaMolina JM, Arrebola JP \& Olea N 2011 Relationship between occupational social class and exposure to organochlorine pesticides 
during pregnancy. Chemosphere 83 831-838. (doi:10.1016/j.chemosphere.2011.02.076)

Gadupudi G, Gourronc FA, Ludewig G, Robertson LW \& Klingelhutz AJ 2014 PCB126 inhibits adipogenesis of human preadipocytes. Toxicology in Vitro 29 132-141. (doi:10.1016/j.tiv.2014.09.015)

Gasull M, Pumarega J, Rovira G, Lopez T, Alguacil J \& Porta M 2013 Relative effects of educational level and occupational social class on body concentrations of persistent organic pollutants in a representative sample of the general population of Catalonia, Spain. Environment International 60 190-201. (doi:10.1016/j.envint.2013.08.001)

Gilsanz V, Hu HH \& Kajimura S 2013 Relevance of brown adipose tissue in infancy and adolescence. Pediatric Research 73 3-9. (doi:10.1038/pr. 2012.141)

Giordano A, Smorlesi A, Frontini A, Barbatelli G \& Cinti S 2014 White, brown and pink adipocytes: the extraordinary plasticity of the adipose organ. European Journal of Endocrinology 170 R159-R171. (doi:10.1530/ EJE-13-0945)

Giralt M \& Villarroya F 2013 White, brown, beige/brite: different adipose cells for different functions? Endocrinology 154 2992-3000. (doi:10.1210/en.2013-1403)

Green B \& Duffull SB 2004 What is the best size descriptor to use for pharmacokinetic studies in the obese? British Journal of Clinical Pharmacology 58 119-133. (doi:10.1111/j.1365-2125.2004.02157.x)

Grun F \& Blumberg B 2006 Environmental obesogens: organotins and endocrine disruption via nuclear receptor signaling. Endocrinology 147 S50-S55. (doi:10.1210/en.2005-1129)

Gutleb AC, Freitas J, Murk AJ, Verhaegen S, Ropstad E, Udelhoven T, Hoffmann L \& Audinot JN 2012 NanoSIMS50 - a powerful tool to elucidate cellular localization of halogenated organic compounds. Analytical and Bioanalytical Chemistry 404 2693-2698. (doi:10.1007/ s00216-012-6066-8)

Hakkak R, Holley AW, Macleod SL, Simpson PM, Fuchs GJ, Jo CH, KieberEmmons T \& Korourian S 2005 Obesity promotes 7,12-dimethylbenz(a) anthracene-induced mammary tumor development in female Zucker rats. Breast Cancer Research 7 R627-R633. (doi:10.1186/bcr1263)

Hakkak R, MacLeod S, Shaaf S, Holley AW, Simpson P, Fuchs G, Jo CH, Kieber-Emmons T \& Korourian S 2007 Obesity increases the incidence of 7,12-dimethylbenz(a)anthracene-induced mammary tumors in an ovariectomized Zucker rat model. International Journal of Oncology 30 557-563. (doi:10.3892/ijo.30.3.557)

Ham M \& Moon A 2013 Inflammatory and microenvironmental factors involved in breast cancer progression. Archives of Pharmacal Research 36 1419-1431. (doi:10.1007/s12272-013-0271-7)

Harvey AE, Lashinger LM \& Hursting SD 2011 The growing challenge of obesity and cancer: an inflammatory issue. Annals of the New York Academy of Sciences 1229 45-52. (doi:10.1111/j.1749-6632.2011. 06096.x)

Hassiotou F \& Geddes D 2013 Anatomy of the human mammary gland: current status of knowledge. Clinical Anatomy 26 29-48. (doi:10.1002/ ca.22165)

Hebert JR, Wirth M, Davis L, Davis B, Harmon BE, Hurley TG, Drayton R, Angela Murphy E, Shivappa N, Wilcox S et al. 2013 C-reactive protein levels in African Americans: a diet and lifestyle randomized community trial. American Journal of Preventive Medicine 45 430-440. (doi:10.1016/j. amepre.2013.05.011)

Hernandez F, Portoles T, Pitarch E \& Lopez FJ 2009 Searching for anthropogenic contaminants in human breast adipose tissues using gas chromatography-time-of-flight mass spectrometry. Journal of Mass Spectrometry 44 1-11. (doi:10.1002/jms.1538)

Hilakivi-Clarke L \& de Assis S 2006 Fetal origins of breast cancer. Trends in Endocrinology and Metabolism 17 340-348. (doi:10.1016/j.tem.2006. 09.002)

Hilakivi-Clarke L, Wang C, Kalil M, Riggins R \& Pestell RG 2004 Nutritional modulation of the cell cycle and breast cancer. Endocrine-Related Cancer 11 603-622. (doi:10.1677/erc.1.00665)
Hilakivi-Clarke L, Luoto R, Huttunen T \& Koskenvuo M 2005 Pregnancy weight gain and premenopausal breast cancer risk. Journal of Reproductive Medicine 50 811-816.

Hilvo M, Denkert C, Lehtinen L, Muller B, Brockmoller S, Seppanen-Laakso T, Budczies J, Bucher E, Yetukuri L, Castillo S et al. 2011 Novel theranostic opportunities offered by characterization of altered membrane lipid metabolism in breast cancer progression. Cancer Research $\mathbf{7 1}$ 3236-3245. (doi:10.1158/0008-5472.CAN-10-3894)

Hopperton KE, Duncan RE, Bazinet RP \& Archer MC 2014 Fatty acid synthase plays a role in cancer metabolism beyond providing fatty acids for phospholipid synthesis or sustaining elevations in glycolytic activity. Experimental Cell Research 320 302-310. (doi:10.1016/j.yexcr. 2013.10.016)

Hovey RC, Trott JF \& Vonderhaar BK 2002 Establishing a framework for the functional mammary gland: from endocrinology to morphology. Journal of Mammary Gland Biology and Neoplasia 7 17-38. (doi:10.1023/ A:1015766322258)

Huang Z, Hankinson SE, Colditz GA, Stampfer MJ, Hunter DJ, Manson JE, Hennekens CH, Rosner B, Speizer FE \& Willett WC 1997 Dual effects of weight and weight gain on breast cancer risk. Journal of the American Medical Association 278 1407-1411. (doi:10.1001/jama.1997. 03550170037029)

Hunt DA, Lane HM, Zygmont ME, Dervan PA \& Hennigar RA 2007 mRNA stability and overexpression of fatty acid synthase in human breast cancer cell lines. Anticancer Research 27 27-34.

Hwang MS, Yu N, Stinson SY, Yue P, Newman RJ, Allan BB \& Dornan D $2013 \mathrm{miR}-221 / 222$ targets adiponectin receptor 1 to promote the epithelial-to-mesenchymal transition in breast cancer. PLOS ONE $\mathbf{8}$ e66502. (doi:10.1371/journal.pone.0066502)

Ibarguren M, Lopez DJ \& Escriba PV 2014 The effect of natural and synthetic fatty acids on membrane structure, microdomain organization, cellular functions and human health. Biochimica et Biophysica Acta 1838 1518-1528. (doi:10.1016/j.bbamem.2013.12.021)

Jemal A, Siegel R, Ward E, Murray T, Xu J \& Thun MJ 2007 Cancer statistics, 2007. CA: A Cancer Journal for Clinicians $\mathbf{5 7}$ 43-66. (doi:10.3322/ canjclin.57.1.43)

Jones PD, Hu W, De Coen W, Newsted JL \& Giesy JP 2003 Binding of perfluorinated fatty acids to serum proteins. Environmental Toxicology and Chemistry 22 2639-2649. (doi:10.1897/02-553)

Karastergiou K, Smith SR, Greenberg AS \& Fried SK 2012 Sex differences in human adipose tissues - the biology of pear shape. Biology of Sex Differences 3 13. (doi:10.1186/2042-6410-3-13)

Kerley-Hamilton JS, Trask HW, Ridley CJ, Dufour E, Ringelberg CS, Nurinova N, Wong D, Moodie KL, Shipman SL, Moore JH et al. 2012 Obesity is mediated by differential aryl hydrocarbon receptor signaling in mice fed a Western diet. Environmental Health Perspectives 120 1252-1259. (doi:10.1289/ehp.1205003)

Khan A, Aljarbou AN, Aldebasi YH, Faisal SM \& Khan MA 2014 Resveratrol suppresses the proliferation of breast cancer cells by inhibiting fatty acid synthase signaling pathway. Cancer Epidemiology 38 765-772. (doi:10.1016/j.canep.2014.09.006)

Kim KY, Kim DS, Lee SK, Lee IK, Kang JH, Chang YS, Jacobs DR, Steffes M \& Lee DH 2010 Association of low-dose exposure to persistent organic pollutants with global DNA hypomethylation in healthy Koreans. Environmental Health Perspectives 118 370-374. (doi:10.1289/ehp. 0901131)

Kim MJ, Pelloux V, Guyot E, Tordjman J, Bui LC, Chevallier A, Forest C, Benelli C, Clement K \& Barouki R 2012 Inflammatory pathway genes belong to major targets of persistent organic pollutants in adipose cells. Environmental Health Perspectives 120 508-514. (doi:10.1289/ehp. 1104282)

Kim BM, Rhee JS, Hwang UK, Seo JS, Shin KH \& Lee JS 2014 Dose- and timedependent expression of aryl hydrocarbon receptor $(A h R)$ and aryl hydrocarbon receptor nuclear translocator $(A R N T)$ in PCB-, $\mathrm{B}[a] \mathrm{P}-$-, and TBT-exposed intertidal copepod Tigriopus japonicus. Chemosphere 120C 398-406. (doi:10.1016/j.chemosphere.2014.07.099) 
Kuemmerle NB, Rysman E, Lombardo PS, Flanagan AJ, Lipe BC, Wells WA, Pettus JR, Froehlich HM, Memoli VA, Morganelli PM et al. 2011 Lipoprotein lipase links dietary fat to solid tumor cell proliferation. Molecular Cancer Therapeutics 10 427-436. (doi:10.1158/1535-7163. MCT-10-0802)

La Merrill M, Emond C, Kim MJ, Antignac JP, Le Bizec B, Clement K, Birnbaum LS \& Barouki R 2013 Toxicological function of adipose tissue: focus on persistent organic pollutants. Environmental Health Perspectives 121 162-169. (doi:10.1289/ehp.1205485)

Lara LA, Duarte AA, Reis RM, Vieira CS \& Rosa-e-Silva AC 2012 Endocrine disrupters: potential risk factors affecting sexual function in both men and women. Journal of Sexual Medicine 9 941-942. (doi:10.1111/j.17436109.2011.02596.x)

Lautenbach A, Budde A, Wrann CD, Teichmann B, Vieten G, Karl T \& Nave H 2009 Obesity and the associated mediators leptin, estrogen and IGF-I enhance the cell proliferation and early tumorigenesis of breast cancer cells. Nutrition and Cancer 61 484-491. (doi:10.1080/0163558080 2610115)

Lee DH, Steffes MW, Sjodin A, Jones RS, Needham LL \& Jacobs DR Jr 2010 Low dose of some persistent organic pollutants predicts type 2 diabetes: a nested case-control study. Environmental Health Perspectives 118 1235-1242. (doi:10.1289/ehp.0901480)

Lemaire G, Mnif W, Mauvais P, Balaguer P \& Rahmani R 2006 Activation of $\alpha$ - and $\beta$-estrogen receptors by persistent pesticides in reporter cell lines. Life Sciences 79 1160-1169. (doi:10.1016/j.lfs.2006.03.023)

Letcher RJ, Bustnes JO, Dietz R, Jenssen BM, Jorgensen EH, Sonne C, Verreault J, Vijayan MM \& Gabrielsen GW 2010 Exposure and effects assessment of persistent organohalogen contaminants in arctic wildlife and fish. Science of the Total Environment 408 2995-3043. (doi:10.1016/j. scitotenv.2009.10.038)

Ljunggren SA, Helmfrid I, Salihovic S, van Bavel B, Wingren G, Lindahl M \& Karlsson H 2014 Persistent organic pollutants distribution in lipoprotein fractions in relation to cardiovascular disease and cancer. Environment International 65 93-99. (doi:10.1016/j.envint.2013.12.017)

Lv Z, Li G, Li Y, Ying C, Chen J, Chen T, Wei J, Lin Y, Jiang Y, Wang Y et al. 2013 Glucose and lipid homeostasis in adult rat is impaired by early-life exposure to perfluorooctane sulfonate. Environmental Toxicology $\mathbf{2 8}$ 532-542. (doi:10.1002/tox.20747)

Mackenbach JP, Stirbu I, Roskam AJ, Schaap MM, Menvielle G, Leinsalu M \& Kunst AE 2008 Socioeconomic inequalities in health in 22 European countries. New England Journal of Medicine 358 2468-2481. (doi:10. 1056/NEJMsa0707519)

Magliano DJ, Loh VH, Harding JL, Botton J \& Shaw JE 2014 Persistent organic pollutants and diabetes: a review of the epidemiological evidence. Diabetes \& Metabolism 40 1-14. (doi:10.1016/j.diabet.2013. 09.006)

Matsuda M \& Shimomura I 2013 Increased oxidative stress in obesity: implications for metabolic syndrome, diabetes, hypertension, dyslipidemia, atherosclerosis, and cancer. Obesity Research \& Clinical Practice 7 e330-e341. (doi:10.1016/j.orcp.2013.05.004)

McManaman JL 2014 Lipid transport in the lactating mammary gland. Journal of Mammary Gland Biology and Neoplasia 19 35-42. (doi:10.1007/ s10911-014-9318-8)

Medina CM, Pitarch E, Portoles T, Lopez FJ \& Hernandez F 2009 GC-MS/MS multi-residue method for the determination of organochlorine pesticides, polychlorinated biphenyls and polybrominated diphenyl ethers in human breast tissues. Journal of Separation Science $\mathbf{3 2}$ 2090-2102. (doi:10.1002/jssc.200800737)

Meeker JD 2012 Exposure to environmental endocrine disruptors and child development. Archives of Pediatrics \& Adolescent Medicine 166 E1-E7. (doi:10.1001/archpediatrics.2012.241)

Murray MJ, Saini HK, van Dongen S, Palmer RD, Muralidhar B, Pett MR, Piipari M, Thornton CM, Nicholson JC, Enright AJ et al. 2010 The two most common histological subtypes of malignant germ cell tumour are distinguished by global microRNA profiles, associated with differential transcription factor expression. Molecular Cancer 9 290. (doi:10.1186/ 1476-4598-9-290)

Myre M \& Imbeault P 2014 Persistent organic pollutants meet adipose tissue hypoxia: does cross-talk contribute to inflammation during obesity? Obesity Reviews 15 19-28. (doi:10.1111/obr.12086)

Nalabolu MR, Palasamudram K \& Jamil K 2014 Adiponectin and leptin molecular actions and clinical significance in breast cancer. International Journal of Hematology-Oncology and Stem Cell Research 8 31-40.

Newman LA, Mason J, Cote D, Vin Y, Carolin K, Bouwman D \& Colditz GA 2002 African-American ethnicity, socioeconomic status, and breast cancer survival: a meta-analysis of 14 studies involving over 10,000 African-American and 40,000 White American patients with carcinoma of the breast. Cancer 94 2844-2854. (doi:10.1002/cncr.10575)

Nguyen DH, Fredlund E, Zhao W, Perou CM, Balmain A, Mao JH \& Barcellos-Hoff MH 2013 Murine microenvironment metaprofiles associate with human cancer etiology and intrinsic subtypes. Clinical Cancer Research 19 1353-1362. (doi:10.1158/1078-0432.CCR-12-3554)

Nielsen NH \& Hansen JP 1980 Breast cancer in Greenland - selected epidemiological, clinical, and histological features. Journal of Cancer Research and Clinical Oncology 98 287-299. (doi:10.1007/BF00410791)

Noyes PD, McElwee MK, Miller HD, Clark BW, Van Tiem LA, Walcott KC, Erwin KN \& Levin ED 2009 The toxicology of climate change: environmental contaminants in a warming world. Environment International 35 971-986. (doi:10.1016/j.envint.2009.02.006)

de Oliveira Andrade F, Fontelles CC, Rosim MP, de Oliveira TF, de Melo Loureiro AP, Mancini-Filho J, Rogero MM, Moreno FS, de Assis S, Barbisan LF et al. 2014 Exposure to lard-based high-fat diet during fetal and lactation periods modifies breast cancer susceptibility in adulthood in rats. Journal of Nutritional Biochemistry 25 613-622. (doi:10.1016/j. jnutbio.2014.02.002)

Park J, Morley TS, Kim M, Clegg DJ \& Scherer PE 2014a Obesity and cancer mechanisms underlying tumour progression and recurrence. Nature Reviews. Endocrinology 10 455-465. (doi:10.1038/nrendo.2014.94)

Park J, Cho SY, Lee SB, Son H \& Jeong H 2014b Obesity is associated with higher risk of prostate cancer detection in a biopsy population in Korea. BJU International 114 891-895. (doi:10.1111/bju.12600)

Parmar H \& Cunha GR 2004 Epithelial-stromal interactions in the mouse and human mammary gland in vivo. Endocrine-Related Cancer $\mathbf{1 1}$ 437-458. (doi:10.1677/erc.1.00659)

Pavlovich AL, Manivannan S \& Nelson CM 2010 Adipose stroma induces branching morphogenesis of engineered epithelial tubules. Tissue Engineering. Part A 16 3719-3726. (doi:10.1089/ten.tea.2009.0836)

Pereira-Fernandes A, Dirinck E, Dirtu AC, Malarvannan G, Covaci A, Van Gaal L, Vanparys C, Jorens PG \& Blust R 2014 Expression of obesity markers and Persistent Organic Pollutants levels in adipose tissue of obese patients: reinforcing the obesogen hypothesis? PLOS ONE 9 e84816. (doi:10.1371/journal.pone.0084816)

Pestana D, Faria G, Sa C, Fernandes VC, Teixeira D, Norberto S, Faria A, Meireles M, Marques C, Correia-Sa L et al. 2014 Persistent organic pollutant levels in human visceral and subcutaneous adipose tissue in obese individuals - depot differences and dysmetabolism implications. Environmental Research 133 170-177. (doi:10.1016/j.envres.2014. 05.026)

Petreas M, Smith D, Hurley S, Jeffrey SS, Gilliss D \& Reynolds P 2004 Distribution of persistent, lipid-soluble chemicals in breast and abdominal adipose tissues: lessons learned from a breast cancer study. Cancer Epidemiology, Biomarkers \& Prevention 13 416-424.

Petreas M, Nelson D, Brown FR, Goldberg D, Hurley S \& Reynolds P 2011 High concentrations of polybrominated diphenylethers (PBDEs) in breast adipose tissue of California women. Environment International 37 190-197. (doi:10.1016/j.envint.2010.09.001)

Pham do Q, Ommerborn MJ, Hickson DA, Taylor HA \& Clark CR 2014 Neighborhood safety and adipose tissue distribution in African Americans: the Jackson Heart Study. PLOS ONE 9 e105251. (doi:10.1371/journal.pone.0105251) 
Planey SL, Kumar R \& Arnott JA 2014 Estrogen receptors (ER $\alpha$ versus ER $\beta$ ): friends or foes in human biology? Journal of Receptor and Signal Transduction Research 34 1-5. (doi:10.3109/10799893.2013.853188)

Pombo M \& Castro-Feijoo L 2005 Endocrine disruptors. Journal of Pediatric Endocrinology \& Metabolism 18 (Suppl 1) 1145-1155. (doi:10.1515/ JPEM.2005.18.S1.1145)

Popkin BM, Adair LS \& Ng SW 2012 Global nutrition transition and the pandemic of obesity in developing countries. Nutrition Reviews 70 3-21. (doi:10.1111/j.1753-4887.2011.00456.x)

Prieto-Hontoria PL, Perez-Matute P, Fernandez-Galilea M, Bustos M, Martinez JA \& Moreno-Aliaga MJ 2011 Role of obesity-associated dysfunctional adipose tissue in cancer: a molecular nutrition approach. Biochimica et Biophysica Acta 1807 664-678. (doi:10.1016/j.bbabio. 2010.11.004)

Priyanka HP, Sharma U, Gopinath S, Sharma V, Hima L \& ThyagaRajan S 2013 Menstrual cycle and reproductive aging alters immune reactivity, NGF expression, antioxidant enzyme activities, and intracellular signaling pathways in the peripheral blood mononuclear cells of healthy women. Brain, Behavior, and Immunity 32 131-143. (doi:10.1016/j.bbi.2013.03.008)

Proia DA \& Kuperwasser C 2006 Reconstruction of human mammary tissues in a mouse model. Nature Protocols 1 206-214. (doi:10.1038/ nprot.2006.31)

Protani M, Coory M \& Martin JH 2010 Effect of obesity on survival of women with breast cancer: systematic review and meta-analysis. Breast Cancer Research and Treatment 123 627-635. (doi:10.1007/s10549-010-0990-0)

Puig T, Porta R \& Colomer R 2009 Fatty acid synthase: a new anti-tumor target. Medicina Clínica 132 359-363. (doi:10.1016/j.medcli.2008. 07.022)

Reynolds P, Hurley SE, Petreas M, Goldberg DE, Smith D, Gilliss D, Mahoney ME \& Jeffrey SS 2005 Adipose levels of dioxins and risk of breast cancer. Cancer Causes Control 16 525-535. (doi:10.1007/s10552004-7840-5)

Richmond A \& Su Y 2008 Mouse xenograft models vs GEM models for human cancer therapeutics. Disease Models \& Mechanisms 1 78-82. (doi:10.1242/dmm.000976)

Ritter L, Solomon K, Sibley P, Hall K, Keen P, Mattu G \& Linton B 2002 Sources, pathways, and relative risks of contaminants in surface water and groundwater: a perspective prepared for the Walkerton inquiry. Journal of Toxicology and Environmental Health. Part A 65 1-142. (doi:10.1080/152873902753338572)

Romero-Figueroa Mdel S, Garduno-Garcia Jde J, Duarte-Mote J, MatuteGonzalez G, Gomez-Villanueva A \& De la Cruz-Vargas J 2013 Insulin and leptin levels in obese patients with and without breast cancer. Clinical Breast Cancer 13 482-485. (doi:10.1016/j.clbc.2013.08.001)

Roos V, Ronn M, Salihovic S, Lind L, van Bavel B, Kullberg J, Johansson L, Ahlstrom H \& Lind PM 2013 Circulating levels of persistent organic pollutants in relation to visceral and subcutaneous adipose tissue by abdominal MRI. Obesity 21 413-418. (doi:10.1002/oby.20267)

Rose DP \& Vona-Davis L 2014 Biochemical and molecular mechanisms for the association between obesity, chronic inflammation, and breast cancer. BioFactors 40 1-12. (doi:10.1002/biof.1109)

Rosenwald M \& Wolfrum C 2014 The origin and definition of brite versus white and classical brown adipocytes. Adipocyte 3 4-9. (doi:10.4161/ adip.26232)

Russo J 1983 Basis of cellular autonomy in the susceptibility to carcinogenesis. Toxicologic Pathology 11 149-166. (doi:10.1177/ 019262338301100207)

Russo J, Gusterson BA, Rogers AE, Russo IH, Wellings SR \& van Zwieten MJ 1990 Comparative study of human and rat mammary tumorigenesis. Laboratory Investigation 62 244-278. (doi:10.1007/978-1-4612-04855_15)

Ruzzin J, Petersen R, Meugnier E, Madsen L, Lock EJ, Lillefosse H, Ma T, Pesenti S, Sonne SB, Marstrand TT et al. 2010 Persistent organic pollutant exposure leads to insulin resistance syndrome. Environmental Health Perspectives 118 465-471. (doi:10.1289/ehp.0901321)
Rylander L, Rignell-Hydbom A, Tinnerberg H \& Jonsson BA 2014 Trends in human concentrations of endocrine disruptors: possible reasons and consequences. Journal of Epidemiology and Community Health 68 4-5. (doi:10.1136/jech-2012-201508)

Salameh TS, Le TT, Nichols MB, Bauer E, Cheng J \& Camarillo IG 2013 An ex vivo co-culture model system to evaluate stromal-epithelial interactions in breast cancer. International Journal of Cancer $\mathbf{1 3 2}$ 288-296. (doi:10.1002/ijc.27672)

Salisbury TB, Morris GZ, Tomblin JK, Chaudhry AR, Cook CR \& Santanam N 2013 Aryl hydrocarbon receptor ligands inhibit IGF-II and adipokine stimulated breast cancer cell proliferation. ISRN Endocrinology 2013 104850. (doi:10.1155/2013/104850)

Sanders J \& Samuelson DJ 2014 Significant overlap between human genome-wide association-study nominated breast cancer risk alleles and rat mammary cancer susceptibility loci. Breast Cancer Research $\mathbf{1 6}$ R14. (doi:10.1186/bcr3607)

Santen RJ, Yue W \& Wang JP 2014 Estrogen metabolites and breast cancer. Steroids (In Press). (doi:10.1016/j.steroids.2014.08.003)

Saxena NK \& Sharma D 2010 Metastasis suppression by adiponectin: LKB1 rises up to the challenge. Cell Adhesion \& Migration 4 358-362. (doi:10.4161/cam.4.3.11541)

Saxena NK, Taliaferro-Smith L, Knight BB, Merlin D, Anania FA, O'Regan RM \& Sharma D 2008 Bidirectional crosstalk between leptin and insulinlike growth factor-I signaling promotes invasion and migration of breast cancer cells via transactivation of epidermal growth factor receptor. Cancer Research 68 9712-9722. (doi:10.1158/0008-5472. CAN-08-1952)

Schnitt SJ 2001 Benign breast disease and breast cancer risk: potential role for antiestrogens. Clinical Cancer Research 7 4419s-4422s discussion 4411 s-4412s.

Schwab U, Lauritzen L, Tholstrup T, Haldorssoni T, Riserus U, Uusitupa M \& Becker W 2014 Effect of the amount and type of dietary fat on cardiometabolic risk factors and risk of developing type 2 diabetes, cardiovascular diseases, and cancer: a systematic review. Food \& Nutrition Research 58 24145. (doi:10.3402/fnr.v58.25145)

Seale P \& Lazar MA 2009 Brown fat in humans: turning up the heat on obesity. Diabetes 58 1482-1484. (doi:10.2337/db09-0622)

Seale P, Kajimura S \& Spiegelman BM 2009 Transcriptional control of brown adipocyte development and physiological function - of mice and men. Genes and Development 23 788-797. (doi:10.1101/gad. 1779209)

Shan Q, Wang J, Huang F, Lv X, Ma M \& Du Y 2014 Augmented atherogenesis in ApoE-null mice co-exposed to polychlorinated biphenyls and 2,3,7,8-tetrachlorodibenzo-p-dioxin. Toxicology and Applied Pharmacology 276 136-146. (doi:10.1016/j.taap.2014.02.007)

Shepel LA \& Gould MN 1999 The genetic components of susceptibility to breast cancer in the rat. Progress in Experimental Tumor Research 35 158-169. (doi:10.1159/000062012)

Shoushtari AN, Michalowska AM \& Green JE 2007 Comparing genetically engineered mouse mammary cancer models with human breast cancer by expression profiling. Breast Disease 28 39-51.

Siddiqui RA, Harvey KA, Zaloga GP \& Stillwell W 2007 Modulation of lipid rafts by $\Omega-3$ fatty acids in inflammation and cancer: implications for use of lipids during nutrition support. Nutrition in Clinical Practice 22 74-88. (doi:10.1177/011542650702200174)

Simpson ER 2003 Sources of estrogen and their importance. Journal of Steroid Biochemistry and Molecular Biology 86 225-230. (doi:10.1016/ S0960-0760(03)00360-1)

Solomon GM \& Schettler T 2000 Environment and health: 6. Endocrine disruption and potential human health implications. CMAJ: Canadian Medical Association Journal 163 1471-1476.

Sonne C 2010 Health effects from long-range transported contaminants in Arctic top predators: an integrated review based on studies of polar bears and relevant model species. Environment International 36 461-491. (doi:10.1016/j.envint.2010.03.002) 
Sorlie T, Perou CM, Tibshirani R, Aas T, Geisler S, Johnsen H, Hastie T, Eisen MB, van de Rijn M, Jeffrey SS et al. 2001 Gene expression patterns of breast carcinomas distinguish tumor subclasses with clinical implications. PNAS 98 10869-10874. (doi:10.1073/pnas.191367098)

Stephenson GD \& Rose DP 2003 Breast cancer and obesity: an update. Nutrition and Cancer 45 1-16. (doi:10.1207/S15327914NC4501_1)

Suba Z 2013 Circulatory estrogen level protects against breast cancer in obese women. Recent Patents on Anti-Cancer Drug Discovery 8 154-167. (doi:10.2174/1574892811308020004)

Sun X, Casbas-Hernandez P, Bigelow C, Makowski L, Joseph Jerry D, Smith Schneider S \& Troester MA 2012 Normal breast tissue of obese women is enriched for macrophage markers and macrophage-associated gene expression. Breast Cancer Research and Treatment 131 1003-1012. (doi:10.1007/s10549-011-1789-3)

Sundaram S, Johnson AR \& Makowski L 2013 Obesity, metabolism and the microenvironment: links to cancer. Journal of Carcinogenesis 1219. (doi:10.4103/1477-3163.119606)

Taylor KW, Novak RF, Anderson HA, Birnbaum LS, Blystone C, Devito M, Jacobs D, Kohrle J, Lee DH, Rylander L et al. 2013 Evaluation of the association between persistent organic pollutants (POPs) and diabetes in epidemiological studies: a national toxicology program workshop review. Environmental Health Perspectives 121 774-783. (doi:10.1289/ ehp.1205502)

Thundiyil JG, Solomon GM \& Miller MD 2007 Transgenerational exposures: persistent chemical pollutants in the environment and breast milk. Pediatric Clinics of North America 54 81-101 ix. (doi:10.1016/j.pcl.2006.11.006)

Valvi D, Mendez MA, Garcia-Esteban R, Ballester F, Ibarluzea J, Goni F, Grimalt JO, Llop S, Marina LS, Vizcaino E et al. 2014 Prenatal exposure to persistent organic pollutants and rapid weight gain and overweight in infancy. Obesity 22 488-496. (doi:10.1002/oby.20603)

Vargo-Gogola T \& Rosen JM 2007 Modelling breast cancer: one size does not fit all. Nature Reviews. Cancer 7 659-672. (doi:10.1038/nrc2193)

Vonderhaar BK 1988 Regulation of development of the normal mammary gland by hormones and growth factors. Cancer Treatment and Research 40 251-266. (doi:10.1007/978-1-4613-1733-3 12)

Walther TC \& Farese RV Jr 2009 The life of lipid droplets. Biochimica et Biophysica Acta 1791 459-466. (doi:10.1016/j.bbalip.2008.10.009)

Warner M, Eskenazi B, Mocarelli P, Gerthoux PM, Samuels S, Needham L, Patterson D \& Brambilla P 2002 Serum dioxin concentrations and breast cancer risk in the Seveso Women's Health Study. Environmental Health Perspectives 110 625-628. (doi:10.1289/ehp.02110625)

Weber R, Gaus C, Tysklind M, Johnston P, Forter M, Hollert H, Heinisch E, Holoubek I, Lloyd-Smith M, Masunaga S et al. 2008 Dioxin- and POP-contaminated sites - contemporary and future relevance and challenges: overview on background, aims and scope of the series. Environmental Science and Pollution Research International 15 363-393. (doi:10.1007/s11356-008-0024-1)

WHO 2000 Obesity: preventing and managing the global epidemic. Report of a WHO consultation. World Health Organization Technical Report Series 894 i-xii. 1-253.

Whyte MB, Velusamy S \& Aylwin SJ 2014 Disease severity and staging of obesity: a rational approach to patient selection. Current Atherosclerosis Reports 16 456. (doi:10.1007/s11883-014-0456-7)

Wilcox S, Sharpe PA, Turner-McGrievy G, Granner M \& Baruth M 2013 Frequency of consumption at fast-food restaurants is associated with dietary intake in overweight and obese women recruited from financially disadvantaged neighborhoods. Nutrition Research 33 636-646. (doi:10.1016/j.nutres.2013.05.007)

Wolff MS, Britton JA, Teitelbaum SL, Eng S, Deych E, Ireland K, Liu Z, Neugut AI, Santella RM \& Gammon MD 2005 Improving organochlorine biomarker models for cancer research. Cancer Epidemiology, Biomarkers \& Prevention 14 2224-2236. (doi:10.1158/ 1055-9965.EPI-05-0173)

Woodwell GM 1967 Toxic substances and ecological cycles. Scientific American 216 24-31. (doi:10.1038/scientificamerican0367-24)

Yu GW, Laseter J \& Mylander C 2011 Persistent organic pollutants in serum and several different fat compartments in humans. Journal of Environmental and Public Health 2011 417980. (doi:10.1155/2011/ 417980)

Zaidi N, Lupien L, Kuemmerle NB, Kinlaw WB, Swinnen JV \& Smans K 2013 Lipogenesis and lipolysis: the pathways exploited by the cancer cells to acquire fatty acids. Progress in Lipid Research 52 585-589. (doi:10.1016/ j.plipres.2013.08.005)

Zeliger HI 2013a Lipophilic chemical exposure as a cause of cardiovascular disease. Interdisciplinary Toxicology 6 55-62. (doi:10.2478/intox-20130010)

Zeliger HI 2013b Lipophilic chemical exposure as a cause of type 2 diabetes (T2D). Reviews on Environmental Health 28 9-20. (doi:10.1515/reveh2012-0031)

Received in final form 20 January 2015

Accepted 26 January 2015

Made available online as an Accepted Preprint

26 January 2015 http://erc.endocrinology-journals.org DOI: 10.1530/ERC-14-0411
(C) 2015 Society for Endocrinology Printed in Great Britain 